\title{
The Epidemiological Impact of STIs among General and Vulnerable Populations of the Amazon Region of Brazil: 30 years of Surveillance
}

\author{
Luiz Fernando Almeida Machado ${ }^{1, *}$, Ricardo Roberto de Souza Fonseca ${ }^{1}$, Maria Alice Freitas Queiroz ${ }^{1}$, \\ Aldemir Branco Oliveira-Filho ${ }^{2}$ D, Izaura Maria Vieira Cayres-Vallinoto ${ }^{1}$, Antonio Carlos Rosário Vallinoto ${ }^{1}$ (D, \\ Marluísa de Oliveira Guimarães Ishak ${ }^{1}$ and Ricardo Ishak ${ }^{1}$ \\ 1 Laboratório de Virologia, Instituto de Ciências Biológica, Universidade Federal do Pará, \\ Belém 66.075-110, Brazil; ricardofonseca285@gmail.com (R.R.d.S.F.); alicefgarcia@gmail.com (M.A.F.Q.); \\ ivallinoto@ufpa.br (I.M.V.C.-V.); vallinoto@ufpa.br (A.C.R.V.); marluisa.malu@gmail.com (M.d.O.G.I.); \\ rishak@ufpa.br (R.I.) \\ 2 Grupo de Estudo e Pesquisa em Populações Vulneráveis, Instituto de Estudos Costeiros, \\ Universidade Federal do Pará, Bragança 68.600-000, Brazil; olivfilho@ufpa.br \\ * Correspondence: lfam@ufpa.br
}

Citation: Machado, L.F.A.; Fonseca, R.R.d.S.; Queiroz, M.A.F.; Oliveira-Filho, A.B.; Cayres-Vallinoto, I.M.V.; Vallinoto, A.C.R.; Ishak, M.d.O.G.; Ishak, R. The Epidemiological Impact of STIs among General and Vulnerable Populations of the Amazon Region of Brazil: 30 years of Surveillance. Viruses 2021, 13, 855. https:/ / doi.org/10.3390/v13050855

Academic Editors: Luciana Barros de Arruda, Fabrício S. Campos and Flavio Guimaraes da Fonseca

Received: 30 March 2021 Accepted: 28 April 2021 Published: 7 May 2021

Publisher's Note: MDPI stays neutral with regard to jurisdictional claims in published maps and institutional affiliations.

Copyright: (c) 2021 by the authors. Licensee MDPI, Basel, Switzerland. This article is an open access article distributed under the terms and conditions of the Creative Commons Attribution (CC BY) license (https:// creativecommons.org/licenses/by/ $4.0 /)$.

\begin{abstract}
Sexually transmitted infections (STIs) represent a worldwide public health problem and, although many of them are curable, they continue to be neglected, especially in areas with a low human development index, such as in the northern region of Brazil. This review describes the results of 30 years of studies at the Virus Laboratory at the Federal University of Pará, including the prevalence and molecular epidemiology of HIV-1, HTLV-1/2, HPV, HBV, Treponema pallidum and Chlamydia trachomatis among urban and non-urban populations, and also in vulnerable groups in the Brazilian Amazon. Control strategies and challenges in preventing STIs are discussed considering this immense geographic region, where essential health services are unable to reach the entire population, especially the most vulnerable, such as female sex workers, people who use illicit drugs, remnants of quilombolos and indigenous communities.
\end{abstract}

Keywords: STI; HIV-1; HTLV; HBV; HPV; T. pallidum; C. trachomatis; epidemiology; Amazon region

\section{Introduction}

Sexually transmitted infections (STIs) represent a severe public health problem, especially among the poorest regions of the world, and cause a profound impact on reproductive and sexual health. The Amazon region stands out, spanning nine countries in South America (Brazil, Bolivia, Peru, Ecuador, Colombia, Venezuela, Guyana, French Guiana and Suriname). Around $60 \%$ of this tropical area is the Brazilian Amazon (Figure 1). Nine Brazilian states are part of this immense tropical region: Acre (AC), Amapá (AP), Amazonas (AM), Mato Grosso (MT), Maranhão (MA), Pará (PA), Rondônia (RO), Roraima (RR) and Tocantins (TO) [1]. These states present a human development index (HDI) below the national average, a vast territory [1] and poor access to health services and the control of diseases, especially sexually transmitted infectious agents.

According to the $\mathrm{WHO}$, more than 1 million STIs are acquired daily worldwide. It is estimated that 38 million people are living with human immunodeficiency virus 1 (HIV-1) [2] and 5 to 10 million people are infected with human T-lymphotropic virus 1 (HTLV-1) [3]. About 300 million women carry human papillomavirus (HPV), the leading cause of cervical cancer and approximately 240 million live with chronic hepatitis B worldwide [4]. Each year, it is estimated that 6.3 million people are infected with Treponema pallidum and 127 million with Chlamydia trachomatis [2,5]. The spread of STIs is also amplified by parenteral and mother-to-child transmission during pregnancy, childbirth or 
the perinatal period, including HIV-1, HTLV-1/2, HPV, hepatitis B virus (HBV), C. trachomatis and T. pallidum [6,7]. The implementation of STI prevention and control strategies cost around USD 18.1 billion from 2016-2021 in 117 low- and middle-income countries, including Brazil [8].

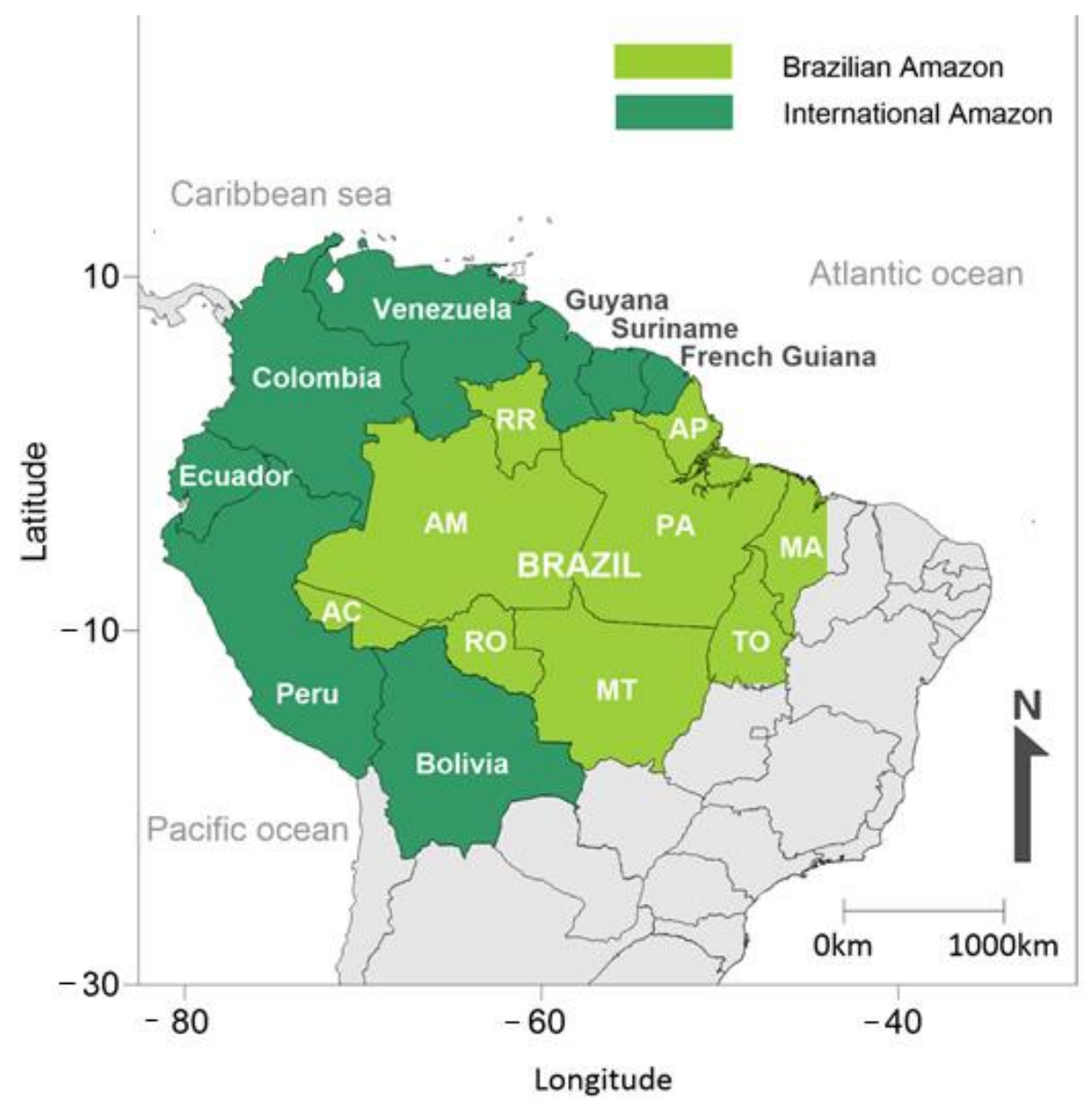

Figure 1. The Amazon rainforest extends over nine countries in South America (Brazil, Bolivia, Peru, Ecuador, Colombia, Venezuela, Guyana, French Guiana and Suriname). Around $60 \%$ of this tropical area is referred to as the Brazilian Amazon. Nine Brazilian states are part of this tropical region: Acre (AC), Amapá (AP), Amazonas (AM), Mato Grosso (MT), Maranhão (MA), Pará (PA), Rondônia (RO), Roraima (RR) and Tocantins (TO).

This review presents the most relevant results of the impact of the infectious agents listed above obtained during the STI epidemiological and clinical research program developed at the Virus Laboratory (VL) of the Biological Sciences Institute of the Federal University of Pará in the last 30 years, with a focus in the Brazilian Amazon region. In addition to generating information about the epidemiology of STIs in the Amazon, we faced the challenge of controlling and preventing these infections in the largest geographic region of Brazil, but with the lowest human development indexes in the country.

\section{Material and Methods}

The first investigations of retroviruses (HIV-1 and HTLV-1/2) included seroprevalence information and looking for specific antibodies, where a screening test was used, usually ELISA tests and a confirmatory test, including Western blotting or indirect immunofluorescence. Subsequently, molecular biology methods such as nested PCR, restriction fragment length polymorphism (RFLP) and nucleotide sequencing were introduced to identify types and subtypes and for phylogenetic analyses. 
For the study of HBV infection, conventional serological methods to detect HBsAg, anti-HBc (IgM and total antibodies) and anti-HBs markers were used as the common methodologies for detecting antigens and antibodies. HPV investigation included dotblot hybridization, polymerase chain reaction, real-time polymerase chain reaction and nucleotide sequencing.

For the investigation of T. pallidum and syphilis, non-treponemal tests (VDRL and RPR) were used as screening methods, and treponemal tests (FTA-abs and ELISA) as a confirmatory method.

The isolation of $C$. trachomatis using cell cultures was restricted to the investigations during the 1980s and 1990s [9]. Since then, the confirmation infection has been based on the detection of short- and long-term antibodies (IgM and $\operatorname{IgG}$ ) for the description of recent and past infections by performing indirect immunofluorescence using $C$. trachomatis serotype L2 as a substrate [9]. The discrimination of seroreactivity to C. trachomatis serotypes and discrimination with C. pneumoniae was by microimmunofluorescence [10]. Subsequently, immunoenzymatic assays [11] were made available for the detection of antibodies. In the 2000s, methods of detecting antigens in situ by immunohistochemistry [12] and nucleic acids were used to confirm infection with $C$. trachomatis $[13,14]$.

The specific technical details for each infectious agent are described in the original publications that accompany the results and discussion of the review.

\section{The Impact of HIV-1 in the Brazilian Amazon: From Description to Current Times}

HIV-1 infection is a major cause of morbidity and mortality in the world and affects a portion of the adult population at the peak of their professional life, causing a great economic impact in many countries [15,16]. The prevalence of HIV-1 infection is higher in population groups that share common risk factors, including men who have sex with men, intravenous drug users, people in prisons and other closed environments, sex workers and trans people [17-19]. Transmission through sexual intercourse remains the most common, although there are several forms of prevention, including the use of condoms and prophylactic pre-exposure schemes (PrEP) [20].

By the end of 2019, over 38 million people living with HIV-1/AIDS (PLHA) were identified worldwide, with almost 1.7 million new infections registered at the time [21]. In Brazil, from 2007 to June 2020, there were 342,459 cases of HIV-1 infection, with 32,263 cases in the Amazon region [22]. The northern region of Brazil has $11.8 \%$ of the cases and an AIDS incidence rate of $24.4 / 100,000$ persons, with the largest number of cases $(43.47 \%)$ occurring in the state of Pará [22]. Four groups have already been identified ( $\mathrm{M}, \mathrm{N}, \mathrm{O}$ and $\mathrm{P})$, nine subtypes (A, B, C, D, F, G, H, J and K), a circulating recombinant form (CRF) and unique recombinant forms (URFs) [23]. In Brazil, subtypes $B$ and F predominate, followed by subtype $C$ and recombinant $B F[24,25]$, except in the southern region, where subtype $\mathrm{C}$ is more common than subtype $\mathrm{F}$ [26]. In the northern region, subtype $\mathrm{B}$ is the most prevalent, and the state of Pará is an important gateway for entry of the virus into the region [27].

The first AIDS cases in Brazil occurred in the middle of 1982, in the city of São Paulo, in the southeastern region of the country, and with the description of HIV-1, the first questions were about the origin of the virus and if some populations described as having greater involvement in the epidemic could already have the infection. In the 1980s, the Virus Laboratory started seroprevalence studies of anti-HIV-1 antibodies, to verify whether the virus was already circulating in several urban population groups (general population, blood donors, male homosexuals and prostitutes) and indigenous people from the Xicrin tribe, among samples collected in the period between 1974 and 1980. The rationale was to investigate groups vulnerable to the acquisition of other STIs, that could already be hosting the virus, and indigenous communities that could provide answers about the ancestry of the infection. There was no evidence of HIV-1 infection, showing that spread of the virus probably did not precede the first cases recorded in Brazil [28]. Clinical and epidemiological information on viral infection were generated by other laboratories [29] 
located in the Brazilian Amazon and it became evident that the epicenter of the epidemic had been the southeast region and the virus rapidly spread to all other regions, including the Amazon region [30].

At the beginning of the epidemic, serological tests (known today as 1st generation) did not yet have great sensitivity and specificity, and the VL was involved in the evaluation of an agglutination test for the detection of anti-HIV antibodies, which could be used for screening in blood banks [31]. Although the prevalence of HIV-1 infection is well known in many locations in Brazil, most studies refer to large urban centers, especially those located in the south and southeast regions. Although HIV-1 has been isolated for more than 30 years, its occurrence in many municipalities located in remote areas of the Amazon region of Brazil is still unknown. The VL was the first in the Brazilian Amazon to describe the seroprevalence of anti-HIV-1 antibodies $(0.6 \%)$ in the Tiriyo indigenous community (Karib linguistic group), which is located in the state of Pará, on the border between Brazil and Suriname, in the 1990s [32]. The low prevalence of HIV-1 infection in several indigenous communities in the Brazilian Amazon was also observed by other Brazilian groups [33,34].

The VL conducted the largest prevalence study of HIV-1 among the general population of four municipalities in the Marajó Archipelago (the largest river archipelago in the world), located in the interior of the state of Pará, showing low prevalence of anti-HIV-1 antibodies $(0.64 \%)$ and confirming a greater circulation of the virus in the state capital [35]. This was corroborated recently, when a low prevalence of HIV-1 infection was also found in a region of the interior of the state of Pará with intense migratory flow due to the construction of a hydroelectric plant [36].

In addition to the general population, highly vulnerable groups were investigated for the acquisition of infection with HIV-1 and other STIs in the Brazilian Amazon region and in other states of Brazil. The VL conducted a pioneering study in the northern region of Brazil in the population of pregnant adolescents in the city of Belém, Pará and identified a low prevalence of HIV-1 infection (0.3\%) [37], similar to that observed in the state of Amazonas [38]. The population of female sex workers (FSWs) is a highly vulnerable group for the acquisition of several STIs, and there are few studies on the epidemiology of HIV-1 in the Brazilian Amazon. A sharp increase in the prevalence of HIV-1 infection was observed from 2005-2006, from 2.3\% [39] to $15.33 \%$ in 2017 [40], showing the spread of the virus towards the interior of the state of Pará over the years.

Another vulnerable population for HIV-1 infection and of which little is known about the epidemiology of STIs are the people who use illicit drugs (PWUD) in the Amazon region. Recently, a high prevalence of HIV-1 infection (15.2\%) has been identified in PWUD in the states of Pará and Amapá. The factors associated with the infection were lower educational level, lower income, crack cocaine use, a longer drug use history and a history of drug injection and engagement in unsafe sex, sex workers and large number of sexual partners [41]. In a collaborative investigation outside the Amazon, there was high prevalence of HIV-1 infection in elderly persons in the neighboring state of Piauí, showing that this group is also susceptible to HIV-1 infection and awareness of risky behaviors should be increased [42].

During the 1990s, the laboratory began investigating the co-infection of HTLV-1/HTLV2 among individuals with HIV-1 in the city of Belém, Pará, as well as the impact on the clinical course of the disease. The first study revealed the occurrence of HIV-1/HTLV co-infection in $8 \%$, with the prevalence of HTLV-2 being higher than that of HTLV-1 [43]. The population groups with major involvement were those who had the highest risk of sexual transmission, a different risk behavior from that seen in Salvador, Bahia, where the highest frequency of co-infection was with HTLV-1 and the main risk was associated with injected drug use [44].

HIV-1/HTLV co-infection studies aided by molecular biology tools, showed a decrease in the occurrence of co-infections over the years in the state of Pará, and the change in the profile of the predominant HTLV subtype. By 2005, the prevalence of co-infection was 3.5\%, with a higher occurrence of HTLV-2c subtype [45] and in 2020, the prevalence dropped 
to $1.4 \%$ with the predominance of the HTLV-1a Cosmopolitan Group, Transcontinental subgroup [46]. Collaborative studies in the state of Piauí, Northeast Brazil, showed the occurrence of $1.61 \%$ co-infection, with HTLV-1a Cosmopolitan Group, Transcontinental subgroup being the most prevalent [47], showing the large regional differences in relation to the epidemiology of this co-infection.

Co-infections were continuously investigated by the VL in other geographical areas of the Amazon, including other STIs. A large variability of C. albicans morphotypes in the oral mucosa of HIV-1 carriers was identified, some of them were highly pathogenic [48] and subgingival sites, especially periodontal pockets, could act as reservoirs for Epstein-Barr virus (EBV) among HIV-1 carriers [49]. A low prevalence of cytomegalovirus (CMV) was observed in the oral mucosa of HIV-1 carriers with gingivitis and chronic periodontitis in the city of Belém, Pará [50]. A high prevalence of HBV co-infection among HIV-1 carriers was observed in the state of Piauí, with the identification of genotypes A, F and D [51] and a low prevalence of hepatitis $\mathrm{C}$ virus (HCV) in Belém, Pará [52]. HPV was detected in small proportion $(26.8 \%)$, with the predominance of types of low oncogenic risk and a positive correlation with the decrease in the amount of CD4 ${ }^{+}$T lymphocytes in HIV-1 patients in Belém, Pará [53], but anti-C. trachomatis and anti-C. pneumoniae antibodies [54] and syphilis [55] were detected at high levels of infection. The investigations presented demonstrate the spread of other STIs among a population group who should be more cautious and oriented to avoid infections which can further compromise their immunological response and boost the inflammatory damage.

Among other groups of co-infections with HIV-1, it was shown that JC virus apparently has no impact on the number of $\mathrm{CD}^{+} \mathrm{T}$ lymphocytes and HIV-1 plasma viral load [56], while GB virus C (GBV-C, currently classified as pegivirus, $\mathrm{HPgV1}$ ) was associated with a decrease in HIV-1 viral load, an increase in $\mathrm{CD}^{+} \mathrm{T}$ lymphocytes and a possible protective effect in the progression of infection to AIDS [57].

After describing key knowledge in the descriptive epidemiology of HIV-1 among population groups in the Amazon region of Brazil, the VL went on to describe the molecular epidemiology of HIV-1, in view of the existent gap at the time. It was shown that Belém, Pará, was one of the most important entry points for HIV-1 into the northern region, due to the great genetic diversity found in the city, between the years 1998 and 2002 [27]. Subtype B was already predominant, followed by subtypes F1, C, D and CRF02_AG, which was the first recombinant subtype identified in this region. During the same period, in the city of Macapá (Amapá), subtypes B and F1 were identified. However, some strains were characterized as $B^{\text {env }} / F^{\text {pro }}, F^{\text {env }} / B^{\text {pro }}$ and $C^{\text {env }} / B^{\text {pro }}$ mosaics [27].

The predominance of HIV-1 subtype $B$, as in most states of the Brazilian Amazon [58-61], was also observed in several population groups investigated by the VL. Subtypes B, F1 and C were among HIV-1-positive pregnant women under ART living in the state of Pará [62] and subtypes B and F1 and the BF1 mosaic among HIV-1 patients undergoing antiretroviral therapy $[63,64]$. Taken together, the identification of the diversity of HIV-1 subtypes suggests a low prevalence of resistance mutations to protease inhibitors, reverse transcriptase and integrase in HIV-1 strains circulating in the northern region of Brazil [62-65].

Progression to AIDS is associated with several factors related to the complex interaction between HIV-1 and the host. The VL started a unique line of investigation looking for gene polymorphisms of the immune and inflammatory responses which could be biomarkers influencing the progression of HIV-1 infection, including mannose-binding lectin $(M B L)$, $I L 6, I F N \gamma, I L-8, I L-10, T G F \beta$ and FAS/FASL genes. The first results obtained in relation to MBL (a serum protein important in the activation of the complement system) showed the presence of $\mathrm{MBL}^{*} \mathrm{~A}, \mathrm{MBL}^{*} \mathrm{~B}$ and $\mathrm{MBL}{ }^{*} \mathrm{D}$ alleles among HIV-1-positive individuals, with the $\mathrm{MBL}^{*} \mathrm{~B}$ variant being associated with higher HIV-1 plasma viral load. This could lead to faster progression to AIDS, considering that a lower concentration of MBL protein in the serum can reduce the activation of the complement system and favor an increase in the plasma viral load of HIV-1 [66]. The investigation of the impact of -550 (H/L) and -221 
$(\mathrm{X} / \mathrm{Y})$ mutations located in the promoter region of the MBL gene on $\mathrm{CD} 4^{+} \mathrm{T}$ lymphocytes and HIV-1 plasma viral load suggested that haplotypes related to medium and low levels of MBL protein in serum might have an important influence on the progression of HIV-1 infection [67].

The only published information on the polymorphisms of chemokine receptors (CCR5D32, CCR2-64I) and chemokine (SDF1-3A) in the population of Belém, Pará showed that the frequency of CCR5-D32 mutation is similar between individuals with and without HIV-1. However, CCR2-64I and SDF1-3A polymorphisms were more frequent in the group of HIV-1-negative individuals, indicating a possible protective effect from HIV-1 infection [68].

The frequency of polymorphisms related to proinflammatory and apoptotic genes, including IFN $\gamma$ (+874T/A), TNF (308G/A), IL-6 (-174G/C), IL-8 (-251A/T), FAS (-670A/G), and FASL $(-124 \mathrm{~A} / \mathrm{G})$, among HIV-1-positive individuals presenting different clinical outcomes (elite controllers, slow long-term non-progressors and progressors) showed three genetic allelic variants of IL6-174G/C, FASL-124A/G and FAS-670A/G polymorphisms related to disease progression and immunological and virological markers in cohorts of HIV-1-positive persons [69]. Polymorphisms in the FAS and FASL genes suggested that the FAS- 670 polymorphism might be associated with apoptosis of $\mathrm{T} \mathrm{CD} 4^{+}$lymphocytes after HIV-1 infection [70].

In the continuing investigation for more accurate biomarkers between genetic polymorphisms and clinical markers of progression to AIDS (including T CD4 $4^{+}$lymphocyte count and HIV-1 plasma viral load), the VL included TNF $\alpha$-308G/A, IFN+874A/T, IL-6$174 \mathrm{C} / \mathrm{G}$, IL-10-1082A/G and TGF $\beta-509 \mathrm{C} / \mathrm{T}$ polymorphisms among HIV-1 carriers. The results suggested that the presence of the IFN $+874 \mathrm{~A}$ allele confers susceptibility to HIV-1 infection and a decrease in the number of $\mathrm{CD}^{+} \mathrm{T}$ lymphocytes and the association of genotype 509TT of TGF $\beta$ with an increase in HIV-1 plasma viral load [71]. Finally, the CYP2B6 G516T polymorphism seems to affect the response to efavirenz treatment by reducing the quantity of $\mathrm{T} \mathrm{CD} 4^{+}$lymphocytes among persons with a high degree of miscegenation who use antiretroviral therapy [72]. The amount of information presented is leading the VL to focus on the more promising results and expanding the investigated groups.

Understanding the variables that control the progression of infection to AIDS has always been one of the key points of research worldwide. Why do some individuals move quickly to AIDS (fast progressors), while others are slow progressors and others do not progress (elite controllers or viremia controllers)? The population of the northern region of Brazil is mixed and this produces strong impact on the genetic background of individuals, and could influence the outcome of HIV-1 infection. The VL studied a cohort to evaluate the genetic profile (polymorphisms of CCR5 $\triangle 32$ and SDF1-3'A) and the plasma levels of eight cytokines (IL-2, IL-4, IL-5, IL-9, IL-10, IL-13, IL-17 and IFN- $\gamma$ ) in three groups of HIV-1-positive individuals, including viremia controllers 1 and 2 (VC1 and VC2) without TARV and a non-controller (NC) group. The results showed that the mean values of $\mathrm{CD}^{+} \mathrm{T}$ lymphocytes were higher among VC than NC, but significantly lower than HIV-1-negative controls and the ratio $\mathrm{CD} 4^{+} \mathrm{T}$ lymphocytes $/ \mathrm{CD}^{+} \mathrm{T}$ lymphocytes could be used as a biomarker for the VC groups. In addition, a clear signature indicated a change from Th1 to Th2 cytokine profiles between VC and NC groups [73]. The investigation of circulating virus showed higher selection pressure on mutations among the virus controllers and a higher frequency of immunological escape mutations in the genes investigated ( $g a g$, nef, rev, tat), with the description of two new mutations in gag. In conclusion, progression to AIDS is a result of the sum of characteristics and pressures exerted by the virus and the interactions with the host immunogenetic characteristics [74].

\section{HTLV-1/2 in the Brazilian Amazon: From Human Migration to Associated Diseases}

HTLV-1 and HTLV-2 are mammalian retroviruses with similarities in their biological and molecular properties [75]. HTLV-1 is associated with fatal diseases, including an aggressive neoplasm (adult T cell leukemia/lymphoma, ATL) and serious inflammatory 
diseases such as HTLV-1-associated myelopathy (HAM), uveitis, dermatitis and arthritis, among other conditions [76]. HTLV-2 is less strongly associated with diseases, but it has been used in the study of human migration markers [77]. HTLV- $1 / 2$ are associated with cells present in organic fluids such as blood, semen, vaginal fluid and breast milk and they are transmitted through sexual, parenteral and mother-to-child pathways (in utero, during childbirth and mainly breastfeeding) [78].

In the context of populations in the Amazon region, the VL defined the endemic transmission of HTLV-2 among indigenous peoples of the Brazilian Amazon [79]. Seroprevalence variations of anti-HTLV-1 and anti-HTLV-2 antibodies in 25 indigenous communities of different ethnicities and language groups showed the occurrence of a new molecular subtype (HTLV-2c), with sexual transmission of the virus as the main transmission route and intrafamilial transmission of HTLV-2 in Kayapó villages, with clear evidence of mother-to-child transmission. This form of transmission was confirmed with the use of molecular biology methods in Kararô village (Kayapó), showing 99.9\% genetic similarity in the sequence of the 5'LTR genomic region of the proviral DNA, between the mother and child infectious strains [80]. The work has been continued up to the present through periodic epidemiological surveillance showing the hyperendemicity of HTLV-2 in other villages of the Kayapó group such as Xikrin do Kateté, Djujeko, Oodjã, Aukre, Kendjan and Pukararankee [81,82]. In contrast, the high prevalence of infection has a very heterogeneous profile in indigenous populations as a result of the processes of the founding effect [83-85]. Epidemiological surveillance has been of great importance and the continued absence of infection in the villages of Araweté and Asurini after 36 years of follow-up is notable [86].

The introduction of molecular biology methods made it possible to perform the complete sequencing of the HTLV-2c genome, initially described among the Kayapó and causing hyperendemic infection in the Brazilian Amazon area [79], in order to look for genomic evidence that could explain the attenuation of the pathogenesis of HTLV-2 in relation to HTLV-1 [87]. Tax gene sequencing showed that HTLV-2c strains identified in urban and indigenous areas of the state of Pará presented the same mutation in the stop codon, identified as a unique aspect of HTLV-2c and which distinguishes it from the HTLV-2a subtype [81].

It was later shown that in addition to indigenous populations, HTLV-2c is already present in urban (blood donors and HIV-1 carriers) and rural populations in the states of Pará and Amazonas [43,82,83,88,89]. In Brazil, HTLV-2c was described in other areas, including São Paulo [90], Rio de Janeiro [91], Belo Horizonte [92], Porto Alegre [93] and Salvador [94]. It is worth mentioning that the virus has been described in Senegal, showing the great capacity of infectious agents to spread [95]. The presence of HTLV-2c in Senegal could be a result of the return of quilombos refugees that occurred soon after the abolition of slavery, to their motherland in Africa following intense interaction with local indigenous peoples [96]. In addition to HTLV-2c, the molecular subtype HTLV-2b was also described in the general population of the city of Belém [97] and among drug users in different municipalities in the state of Pará [98].

HTLV-1 infection in the Amazon has been mostly represented by the presence of the subtypes HTLV-1 transcontinental cosmopolitan and HTLV-1 Japanese cosmopolitan [99-101]. The introduction of HTLV-1 in the Amazon region probably occurred with the human migratory processes resulting from the slave trade from Africa between the 16th and 17th centuries and from the most recent Japanese migration to the Amazon in the late 18th and early 19th centuries $[77,79]$. The introduction of HTLV-1 from the slave trade is suggested by the presence of the virus in quilombola communities in the region [77,96]. Other routes of transmission, such as sharing of instruments for the use of injected drugs, have also been investigated and the prevalence was 3\% for HTLV-1 and 2.3\% for HTLV-2 (2.3\%) in the state of Pará [98]. It is worth mentioning that the circulation of the molecular subtypes HTLV-1 transcontinental cosmopolitan, HTLV-1 Japanese cosmopolitan and HTLV-2c and the presence of HTLV- $2 \mathrm{~b}$ as a molecular variant were introduced by injected drug users. 
The main dissemination of HTLV-1/2 through the sexual route characterizes it as one of the important STIs, of which carriers' sexual behaviors act as facilitators for transmission, i.e., sexual contact without the use of condoms and multiple partners [102]. This was initially shown among HIV-1-positive individuals co-infected with HTLV-1/2, where the main risk factor reported was sex with multiple partners [43]. Among drug users, unprotected sex, the presence of ulcers and wounds in the genitalia and more than 12 sexual partners were factors associated with infection by both viruses [98].

The first cases of disease associated with HTLV-1 in the Amazon region were cases of HAM [103]. Since then, the VL has sought numerous markers of the immunological and inflammatory response [104,105] suggesting the association of genetic factors that lead to the intra-family distribution of the virus [106] and of the progression of disease in the development of HAM and other conditions of inflammatory disease among those infected with HTLV-1 [107,108]. Lung disease has also been reported in patients with HTLV-1 living in the state of Pará [109].

The large geographical distribution of HTLV-1 and HTLV-2 in the Amazon region poses a great challenge to describe the prevalence of HTLV-1/2 [85]. The geographical challenge associated with infrastructure limitations has made it difficult to determine the exact prevalence of infections, even though the virus has been described in several different populations of the Amazon region of Brazil for almost 30 years. As prophylaxis progresses towards a future HTLV-1 vaccine, it is important to determine who is at risk of being infected and possibly developing one of the diseases associated with HTLV-1 in order to implement preventive measures [85].

Prevalence rates and molecular epidemiology of HTLV-1/2 (and HIV-1) are shown in Table 1, which summarizes the results obtained in the different studies in the Amazon region of Brazil.

Table 1. Prevalence rates and molecular epidemiology of HIV-1 and HTLV-1/2 in population groups of the Amazon region of Brazil.

\begin{tabular}{|c|c|c|c|c|c|}
\hline Location & Year of Collection & Group & Prevalence Rate (\%) & Subtypes & Reference \\
\hline \multicolumn{6}{|c|}{ HIV-1 } \\
\hline Goiás & 1980 & $\begin{array}{l}\text { MSM }^{*}, \mathrm{FSW}^{\S} \\
\text { General }\end{array}$ & 0.0 & - & [28] \\
\hline Pará & 1974-1980 & $\begin{array}{l}\text { population, blood } \\
\text { donors, indigenous }\end{array}$ & 0.0 & - & [28] \\
\hline Pará & 1983 & Gold miners & 0.0 & - & [29] \\
\hline Pará & 1996 & Indigenous & 0.6 & B & [32] \\
\hline Pará, Amapá & 1997 & Indigenous & 0.1 & $\mathrm{~B}$ & [33] \\
\hline $\begin{array}{l}\text { Amazonas, } \\
\text { Roraima }\end{array}$ & 2009-2011 & Indigenous & 0.13 & - & [34] \\
\hline Pará & 2012 & $\begin{array}{c}\text { General } \\
\text { population }\end{array}$ & 0.2 & - & [35] \\
\hline Pará & 2005-2014 & $\begin{array}{l}\text { General } \\
\text { population }\end{array}$ & 0.48 & - & [36] \\
\hline Pará & 2009-2010 & $\begin{array}{l}\text { Pregnant } \\
\text { adolescents }\end{array}$ & 0.3 & - & [37] \\
\hline Amazonas & 2008 & Pregnant women & 0.6 & - & [38] \\
\hline Pará & 2005-2006 & FSWs & 2.3 & B, F1 & [39] \\
\hline Pará & 2017 & FSWs & 15.3 & - & [40] \\
\hline Pará; Amapá & $2013-2018$ & PWUD II & 15.2 & - & [41] \\
\hline Piauí & 2007 & Elderly people & 3.7 & - & [42] \\
\hline Pará & 2009 & PLHA & - & $\begin{array}{l}\text { B, F1, C, D, } \\
\text { CRF02_AG }\end{array}$ & [27] \\
\hline Amapá & 2009 & PLHA & - & $\mathrm{B}, \mathrm{F} 1$ & [27] \\
\hline Mato Grosso & 2008-2009 & PLHA & - & B, F1, C, D & [58] \\
\hline
\end{tabular}


Table 1. Cont.

\begin{tabular}{|c|c|c|c|c|c|}
\hline Location & Year of Collection & Group & Prevalence Rate (\%) & Subtypes & Reference \\
\hline \multicolumn{6}{|c|}{ HIV-1 } \\
\hline Tocantins & 2008-2009 & PLHA & - & $\mathrm{B}, \mathrm{C}, \mathrm{F} 1$ & [59] \\
\hline Amazonas & 2006-2007 & PLHA & - & $\mathrm{B}, \mathrm{C}, \mathrm{BF}$ & [60] \\
\hline $\begin{array}{l}\text { Amazonas, } \\
\text { Rondônia, } \\
\text { Roraima }\end{array}$ & 2011-2017 & PLHA & - & $\mathrm{B}, \mathrm{C}, \mathrm{F} 1, \mathrm{BF} 1$ & [61] \\
\hline Pará & 2007-2008 & $\begin{array}{l}\text { Pregnant women } \\
\text { with HIV-1 }\end{array}$ & - & $\mathrm{B}, \mathrm{F}, \mathrm{C}$ & [62] \\
\hline Pará & 2016 & PLHA & - & $\mathrm{B}, \mathrm{F} 1, \mathrm{BF} 1$ & {$[63,65]$} \\
\hline \multicolumn{6}{|c|}{ HTLV-1/2 } \\
\hline Pará, Amapá & 1997 & Indigenous & $0.19-0.29$ & HTLV-2a & [33] \\
\hline Pará & 2009-2010 & $\begin{array}{c}\text { Pregnant } \\
\text { adolescents }\end{array}$ & 0.6 & - & [37] \\
\hline Amazonas & 2008 & Pregnant women & 0.0 & - & [38] \\
\hline Pará & 2005-2006 & FSWs & 1.7 & HTLV-1a & [39] \\
\hline Pará & 1994-1996 & PLHA ${ }^{¥}$ & 4.0 & $\begin{array}{l}\text { HTLV-1; } \\
\text { HTLV-2 }\end{array}$ & [43] \\
\hline Bahia & 1997 & PLHA & 16.3 & $\begin{array}{l}\text { HTLV-1; } \\
\text { HTLV-2 }\end{array}$ & [44] \\
\hline Pará & 2005 & PLHA & 3.5 & $\begin{array}{l}\text { HTLV-1a; } \\
\text { HTLV-2c }\end{array}$ & {$[45]$} \\
\hline Pará & 2016-2017 & PLHA & 1.4 & HTLV-1a & [46] \\
\hline Piauí & 2007 & PLHA & 1.6 & $\begin{array}{l}\text { HTLV-1a; } \\
\text { HTLV-2c }\end{array}$ & [47] \\
\hline Pará & 1983-1991 & Indigenous & 7.8 & HTLV-2a & [79] \\
\hline Pará & $2000(?)$ & Indigenous & - & HTLV-2c & [83] \\
\hline Pará & 2015 & Indigenous & 29.0 & HTLV-2c & [82] \\
\hline Amazonas & 2015-2016 & $\begin{array}{l}\text { Patients with } \\
\text { hematological } \\
\text { diseases }\end{array}$ & 0.32 & HTLV-2c & [88] \\
\hline Pará & 2013-2018 & PWUD & 5.3 & $\begin{array}{l}\text { HTLV-1a, } \\
\text { HTLV-2b, } \\
\text { HTLV-2c }\end{array}$ & [98] \\
\hline Pará & 1999 & $\begin{array}{l}\text { Japanese } \\
\text { immigrants }\end{array}$ & 1,8 & HTLV-1 & [99] \\
\hline Pará & 2006 & $\begin{array}{l}\text { TSP/HAM } \\
\text { General }\end{array}$ & - & HTLV-1a & [100] \\
\hline Pará & $2002-2003$ & $\begin{array}{c}\text { population Marajó } \\
\text { Island }\end{array}$ & 0.11 & HTLV-1a & [101] \\
\hline
\end{tabular}

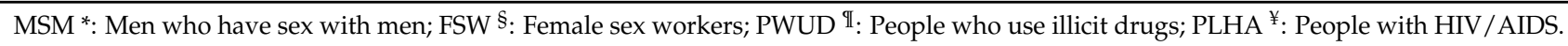

\section{HPV: An Infection with a Chronic Disease Outcome in the Brazilian Amazon}

Some HPV serotypes are sexually transmitted and some are associated with the etiology of cervical cancer, and other types of cancer, including cancer of the anus, vulva, vagina, penis and oropharynx [110]. More than $220 \mathrm{HPV}$ genotypes have been identified [111] and classified as low and high oncogenic risk [112]. In Brazil, the virus is the etiology of approximately $5.1 \%$ of neoplasms in general, and almost $100 \%$ of cervical tumors, $88 \%$ of anal tumors and $50 \%$ of penile tumors. Regarding cervical cancer, there are an estimated 570,000 new cases per year [113].

Although it is one of the most common STIs worldwide, the epidemiology of HPV infection in the Amazon region of Brazil is still poorly known. Among indigenous populations of the Brazilian Amazon region, 22\% of infections were observed among women of the Parakanã tribe [114] and 39.7\% in indigenous communities in the state of Amazonas [115].

Most of the studies investigating the epidemiology of HPV in the northern region of Brazil were among uterine cervical samples from women with or without cervical cancer. 
In the city of Belém, Pará the prevalence of HPV among women with lesions of the uterine cervix showed a prevalence of $70.3 \%$ among women with invasive epidermoid carcinoma or adenocarcinoma, $63 \%$ in patients having either cervical intraepithelial neoplasia grade II or III and $36.8 \%$ in women with chronic cervicitis. In all groups, there was a predominance of subtypes 16 and 18, in addition to the presence of HPV types 31, 33, 45, 52, 58, 59 and 73 [116]. The ethnicity-related distribution of HPV-16 variants was investigated in biopsies from women with cervical intraepithelial neoplasia grade III or invasive cervical cancer. The most prevalent HPV-16 variant was the Asian-American B-2, followed by the European B-12 and the European prototype [117]. Among females living in riverside communities in the state of Pará, HPV prevalence was 16.4\%, with 2.3\% HPV-16 and 1.4\% HPV-18 [118].

There is not sufficient epidemiological information on HPV among vulnerable FSWs. In the only study performed in the state of Amazonas [119] 100\% HPV infection was observed among FSWs and, although the sample size was small, it is indicative of the possible impact of the infection.

Among the female prisoner population group in the municipality of Ananindeua, Pará, the prevalence of cervical HPV was 10.5\% [120], while in riverside women in the state of Pará, the prevalence was $16.4 \%$, with the identification of types 16 and 18 [121]. In women in rural and urban areas in the state of Pará, the prevalence of HPV infection was very similar, with $15 \%$ in urban areas and $14.2 \%$ in rural areas [122]. In the rural areas of the city of Coari, Amazonas, a prevalence of $19.1 \%$ of HPV DNA was identified in a cervical cancer screening study [123]. Female university students from Belém showed a 25.3\% prevalence of HPV and the most prevalent genotype was HPV-61 (5.3\%), followed by HPV-82, HPV-16, HPV-59 and HPV-6 [124]. Among women with autoimmune diseases, the prevalence was similar $(22.8 \%)$, with the higher frequencies of genotypes HPV-58 $(37.5 \%)$ and HPV-31 (31.3\%) [125].

In the city of Belém, Pará, the oral cavity has been investigated and HPV was detected among $24.1 \%$ of individuals without clinically diagnosed lesions, infected with genotypes HPV-6, HPV-18 and HPV-58 [126]. The prevalence of HPV in the oral cavity of people who use crack cocaine was 39.9\%, infected with genotypes 6, 11, 16, 18, 31, 33, 45, 52 and 58, with $12.6 \%$ presenting multiple infections [127].

The presence of cervical and anal HPV infections is common and identification of cervical cancer might contribute to the prevention of anal cancer in women, especially in women living with HIV-1 [128]. The VL identified the types HPV-6, HPV-11, HPV-16, HPV-53, HPV-58, HPV-59, HPV-61, HPV-62, HPV-66, HPV-70, HPV-71 and HPV-102 as causing anal infection among women with HIV-1 in the city of Belém, Pará [53].

\section{HBV: The Impact of the Geographical Area on the Prevalence of the Virus in the Brazilian Amazon}

Hepatitis B virus (HBV) is associated with acute and chronic diseases, including cirrhosis, liver cancer and death [129]. According to the prevalence rates of the serological marker of viral persistence (HBsAg), the endemicity of the virus is classified as low $(<2 \%)$, intermediate-low ( $2 \%$ to $4 \%$ ), intermediate-high (5\% to 7\%) and high ( $8 \%$ ) [129]. The Brazilian Amazon is characterized as a region of high endemicity $[130,131]$, although it is not uniform. High frequencies of HBV-associated diseases and its sequelae have been recorded more frequently in the states of Acre, Amazonas and Rondônia than in other areas of the Amazon region [130,131]. A high lethality rate was associated with hepatitis delta virus (HDV) co-infection among HBsAg carriers in the state of Amazonas [130,132,133]. In Brazil, up to 2018, 233,027 cases of hepatitis B were reported, with approximately 14\% of cases concentrated in the Amazon region [134]. HBV is prevented by safe and effective vaccines that prevent the development of chronic diseases and liver cancer $[135,136]$.

The initial investigations of HBV by the VL were a consequence of the epidemiological information at the time about the extensive spread of the virus and its association with a new infectious agent described in Italy, HDV [133,137,138].

In the 1980s and 1990s, the VL conducted the first seroepidemiological investigation of more than 4000 people residing in seven urban communities in the state of Pará and 24 in- 
digenous communities in the Brazilian Amazon, residing in six states of the region [139] (Table 2). Urban communities showed a clear-cut difference between seroprevalence rates, which were higher in the westernmost areas of the state of Pará (13.2-15.9\%) than those located along the mouth of the Amazon river (6.7-11.8\%) [139]. The prevalence of HBV markers among 2222 indigenous people ranged from $3.4-59.2 \%$. In two communities investigated in the years 1983 and 1985, HBV infections were not found. Unfortunately, however, in 1990, the virus had already entered the community and established persistence in about $10 \%$ of the group [140].

Table 2. Correlation of exposure and persistence levels of HBV among indigenous communities of the Amazon region of Brazil.

\begin{tabular}{ccccc}
\hline Exposure Level & $\begin{array}{c}\text { Persistence } \\
\text { Level }\end{array}$ & $\begin{array}{c}\text { Indigenous } \\
\text { Community }\end{array}$ & Exposure (\%) & Persistence (\%) \\
\hline \multirow{2}{*}{ Low } & Medium & Tiryó & 6.4 & 3.2 \\
& & Asurini do & 5.1 & 3.1 \\
& & Trocorá & 0 & 5.6 \\
Medium & Low & Kikretun & 22 & 0.6 \\
& \multirow{2}{*}{ High } & Munduruku & 17.9 & 0 \\
& & Yamamadi & 26.3 & 14.2 \\
& & Wayana-Apalai & 12.3 & 11.3 \\
\hline & & Yanomami & 24.2 & \\
\hline
\end{tabular}

For the first time, it was possible to show evidence that indigenous communities could modulate HBV infection differently than among urban population groups. The endemicity of the virus at high levels is usually accompanied by high levels of viral persistence. However, some groups were exposed in different ways, but there was no correlation with the levels of persistence. Differently from urban populations, the difference in modulation of HBV infection could be related to the low genetic variability of epidemiologically closed communities when compared with urban tri-hybrid population groups of the Amazon region [139]. The persistence of HBV in epidemiologically closed communities is worrying, since we are dealing with an agent that can be aggressive in terms of outcome (leading to cirrhosis and liver cancer) in a population of enormous vulnerability and without appropriate access to health services.

With the use of molecular biology methods, the investigation of HBV genotypes circulating among virus carriers treated at a university hospital was initiated and showed the predominance of genotype A $(89.1 \%)$, followed by F $(8.7 \%)$ and D $(2.2 \%)$, although there was no influence of genotypes on the clinical manifestations or severity of liver disease [121]. The presence of pre-core and core mutations was detected at low levels and showed no association with the disease staging caused by HBV.

Epidemiological investigations among high-risk groups (FSWs and PWUD) showed prevalence rates of $\mathrm{HBV}$ infection ranging from 3.0\% to $13.7 \%$ among FSWs that offered their services in municipalities and riverside communities in the state of Pará [121,141]. The rate of vaccine immunity (anti-HBs only) ranged from $0.7 \%$ to $4.7 \%$ [141,142] and genotype A $(69.0 \%)$ was the predominant one [143]. Reduced monthly income, low education, unprotected sex, multiple sexual partners, unsafe sexual practices, illicit drug use and co-infection with other STIs have been associated with exposure to HBV $[141,143]$. These findings indicate the need for urgent measures to control the spread of HBV and other STIs and to promote the health of FSWs. The inclusion of these women in vaccination programs and other initiatives in the area of women's health, including periodic gynecological examinations and testing for STIs, provision of condoms and other measures that promote self-care, will help to minimize the impacts on this group of vulnerable people, as well as in the general population.

Immunogenetic studies conducted among patients with chronic HBV residing in the state of Pará have been quite successful in showing associations between the polymor- 
phisms investigated among the immunological system genes (IFN-y, TGF-beta1, IL28b, MBL, PrtCR, IL-10, TLR-3, TLR-4 and FoxP3) and HBV infection. Higher serum levels of IFN-c and TGF-beta1 have been associated with chronic hepatitis $B$, and lower serum levels of IL-10 have been found in patients with active disease. The presence of the TNF- $a 308$ polymorphism allele A suggests a risk of progressive disease [144]. Single nucleotide polymorphisms (SNPs) in the IL28b gene indicated there is no association with the susceptibility and clinical evolution of hepatitis B [145]. SNPs in the TLR3 and TLR4 genes appear to be associated with higher levels of ALT, AST and prothrombin, in addition to being associated with higher levels of GGT [146].

In the investigation of the main SNP in the MBL gene, patients with active HBV who had wildtype AA genotype had a positive correlation between increased levels of transaminases, HBV DNA and the presence of mild to moderate fibrosis [147]. Mutations in the FoxP3 gene, SNP-924 A > G, showed that G carrier status was associated with altered viral loads and liver enzyme levels in patients with chronic active hepatitis B (CHB-A) with inflammation and fibrosis. However, the frequencies of SNP-3279 C > A, A and-924 A $>$ G, G were not directly associated with the histopathological profiles of the patients investigated [148]. It was also observed that the hepatic levels of mRNA expression of the NGF and $p 75 N T R$ genes decreased and increased, respectively, in relation to the stage of inflammatory activity in HBV carriers. A positive correlation between the expression of the p75NTR and NGF genes was observed in livers with mild and moderate fibrosis, although not in cases of severe fibrosis and cirrhosis [149].

Providing efficient services and adequate resources for the diagnosis, treatment and prevention of HBV infection must be extended to all populations in the Brazilian Amazon. The concentration of health services and resources in the main urban cities of the states, the absence or irregular development of strategies to promote health in rural and remote areas (including riverside communities and indigenous tribes), risk behaviors and the low socioeconomic status of the population are relevant factors for the epidemiological scenario of HBV infection in the Brazilian Amazon. They are relevant variables, that if not dealt with, will keep HBV circulating at high or intermediate endemicity in the region over a long period of time.

\section{The Not Yet Defined Impact of Treponema pallidum in the Brazilian Amazon}

Syphilis is an STI caused by T. pallidum, an agent transmitted mainly by contact with infectious wounds on genital organs, in addition to blood or mother-to-child transmission during pregnancy, which includes the epidemiological clinical cases of acquired syphilis in pregnant women and congenital cases [150]. Although syphilis is a treatable and easily diagnosed disease, nearly one million pregnant women presented with syphilis in 2016, resulting in more than 200,000 newborn deaths [151]. In Brazil, in 2020, 152,915 cases of acquired syphilis were registered, with 61,127 cases of syphilis in pregnant women, 24,130 cases of congenital syphilis and 173 deaths from congenital syphilis [152].

The investigation of syphilis and T. pallidum by the VL started in the 1980s, through the screening of milk donor mothers in a public hospital milk bank (unpublished information). Subsequently, the first epidemiological investigation showed that in the general population of Belém, $15.8 \%$ was already infected with T. pallidum, and $4.4 \%$ had an ongoing infection [153]. The absence of the use of condoms during sexual intercourse and the lack of knowledge of syphilis as an STI were the most reported variables among those investigated.

With the approval of new projects that aimed to define the prevalence of STIs, two population groups of crucial importance as reservoirs of T. pallidum were our objects of investigation: HIV-1 carriers and FSWs, among whom an increase in the incidence of syphilis was demonstrated [154]. In a sample of $430 \mathrm{HIV}-1$ carriers, the prevalence of past infections by T. pallidum was $27.2 \%$, and $7.7 \%$ had laboratory results compatible with ongoing syphilis [54]. The use of non-injectable illicit drugs, having more than one sexual partner per week, the practice of anal sex and homosexual/bisexual behavior were associated with exposure to T. pallidum. The greatest importance of this study was in the 
investigation of a population group that should already be looking for basic preventive measures to avoid the transmission of other STIs. In another study with HIV-1 carriers, who were ART naive, the prevalence of T. pallidum was 17.3\% [55].

Among FSWs who lived in three urban locations in the northeast of the state of Pará, the prevalence of syphilis was $14.1 \%$. This infection was associated with the offering of sexual services in low-income areas, a consequence mainly of the low level of education. The practice of anal sex in the first years of sexual intercourse was another important factor associated with syphilis. This proved the urgent need to establish more effective prevention and control actions for the population groups [155].

Recently, an epidemiological report with 180 FSWs offering sexual services in 25 locations in the Marajó Archipelago showed that syphilis was clinically present in $41.1 \%$ of the women investigated [156]. In addition to the low levels of income and education, the use of illicit drugs, a long period of prostitution and the lack of regular medical appointments were factors associated with exposure to T. pallidum. The molecular approach to detect the presence of point mutations (A2058G or A2059G) in the T. pallidum 23S rRNA gene showed that $23.5 \%$ of FSWs were infected with T. pallidum strains with point mutations indicative of resistance to treatment with macrolides. It is important to highlight the increase in infection levels among a population group with high vulnerability, living in places with a low human development index and lacking basic services and reaching women who act as reservoirs for the dissemination of the agent. The presence of T. pallidum among FSWs represents a point of great relevance for the extensive dissemination of the agent to FSWs and the avoidance of reaching a point of difficult control in the entire population of the archipelago.

The STI investigation approach among the general population of four municipalities in the Marajó Archipelago also included seroprevalence of T. pallidum and syphilis. It showed a level of $8.5 \%$ of previous exposure to the bacterium and $4.6 \%$ of recent infections [157]. The distribution of exposure to T. pallidum was found to be among young adults, gradually increasing with age by four times (2.2\% to $9 \%)$. Young adults represent the main group of sexually active individuals and the presence of syphilis in this group is worrying, as it indicates a serious failure in the measures for the prevention and control of syphilis in the Marajó Archipelago.

\section{Infection with C. trachomatis in the Brazilian Amazon and Associated Diseases}

Human diseases associated with infections by bacteria of the genus Chlamydia are worrying public health problems. C. trachomatis is related to eye infections, such as trachoma and inclusion conjunctivitis, and genital infections, such as venereal lymphogranuloma, nongonococcal urethritis, epididymitis, proctitis, salpingitis and mucopurulent cervicitis, which can progress to pelvic inflammatory disease, ectopic pregnancy and infertility [158-161]. The WHO estimates that there are more than 127 million new cases of $C$. trachomatis annually [2,5], which cause additional harm to thousands of women who become infertile [162-164]. The bacterium has well-defined forms of transmission, and the sexual route is probably the most common, making it one of the most important STIs.

Among the 19 serotypes of $C$. trachomatis, A-C are causes of eye infections, D-K cause urogenital infections and L1-L3 cause cases of venereal lymphogranuloma $[165,166]$. The prevalence of genital infections and their complications, by C. trachomatis, in developing countries is not clearly defined and the same is true in Brazil. The absence of laboratory diagnosis of the infection, the lack of notification of cases, the inappropriate use of antibiotics and the failure to apply preventive measures are important variables for the spread of the bacterium.

A study of $C$. trachomatis started at the VL in the 1980s confirmed the presence of antibodies among three specific population groups in the Brazilian Amazon [167]. Different prevalence rates were found in Belém (53.6\%), gold mining areas $(76.2 \%)$ and among the indigenous people of the Xicrin tribe (51.3\%). The expansion of the investigated geographical area and the number of groups showed the spread of $C$. trachomatis among urban 
populations (prenatal clinics, gynecological clinics, STI clinics and FSWs) and indigenous populations (Parakanã and Kubenkokre) with prevalence ranging from 33.3\% to 97.1\% [9]. It is worth mentioning that the use of McCoy cell cultures for the isolation of the bacterium showed that $C$. trachomatis was the most important etiologic agent (30\%) of non-gonococcal urethritis in an STI clinic and also infected asymptomatic women in gynecology and obstetrics clinics [9] in similar percentages previously found in other regions [168].

One of the focuses of the laboratory became the description of the involvement of the bacterium among isolated vulnerable indigenous human populations. A seroepidemiological study involving 2086 people from 27 indigenous communities in six states in the Brazilian Amazon showed an average prevalence of antibodies of $48.6 \%$ and communities which never came into contact with the bacterium; 14 communities showed prevalence rates of up to $50 \%$, six with up to $70 \%$ and nine that reached up to $90.7 \%$ [10]. It was also shown that $1.2 \%$ showed evidence of recent infection and $6.1 \%$ indicated they had persistent infection with $C$. trachomatis. Using microimmunofluorescence, seroreactivity showed infection by $C$. trachomatis serotypes associated with trachoma and STIs. Interestingly, some of the samples showed reactivity by indirect immunofluorescence, but they did not react with any of the antigens of $C$. trachomatis or $C$. pneumoniae, possible evidence that some community members were infected with other species of Chlamydia circulating in nature. Now, when emerging infections cross the inter-species barrier and are transmitted from animals to humans, such as HIV-1 [169], HTLV-3 and HTLV-4 [170] and SARS-CoV-2 [171], the information becomes even more up to date and relevant since we are dealing with vulnerable populations with little access to the health system.

Although there was no evidence of a geographical association with the distribution of prevalence, an interesting epidemiological pattern was present in that communities modulated prevalence levels differently from how Chlamydia was maintained in persistence as previously reported by the VL for HBV [139]. Communities could have low, medium or high levels of infection, and combine low, medium or high levels of persistence (Table 3), which indicated the influence of the genetic component of isolated and semi-isolated indigenous populations [10]. The high prevalence and high rate of persistence of Chlamydia in small indigenous communities are factors of great concern, since among closed communities, it is common to have a greater spread of STIs, including by other means of transmission than sexual routes $[172,173]$. It is worth mentioning that this is a worrying situation since C. trachomatis is associated with infertility and is a determining factor in decreasing the population density of indigenous communities. The situation is further aggravated by the detection of other STI markers, including reactivity to VDRL, persistence of HBV, lesions due to herpes simplex and the presence of Neisseria in children who had vaginal discharge [139].

Table 3. Correlation of exposure and persistence levels of Chlamydia among indigenous communities of the Amazon region of Brazil.

\begin{tabular}{ccccc}
\hline Exposure Level & $\begin{array}{c}\text { Persistence } \\
\text { Level }\end{array}$ & $\begin{array}{c}\text { Indigenous } \\
\text { Community }\end{array}$ & Exposure (\%) & Persistence (\%) \\
\hline Low & Low & Mundurukú & 20.4 & 3.3 \\
Low & Medium & $\begin{array}{c}\text { Arára Laran- } \\
\text { jal/Kurambê }\end{array}$ & 27.7 & 7 \\
Low & High & Tiriyó & 11.5 & 33.3 \\
Medium & Low & Kokrainimôro & 55.9 & 1.9 \\
Medium & Low & Asurini & 61 & 4 \\
Medium & Kedium & Cinta-Larga & 47.1 & 6.2 \\
High & Low & Awa-Guajá & 90.7 & 2.6 \\
High & Medium & Parakanã & 81 & 5.9 \\
High & Medium & Xicrin & 81.5 & 9.5 \\
High & High & Kubenkokrê & 75.8 & 10.1 \\
High & High & Yanomámi & 87.6 & 21.1 \\
\hline
\end{tabular}


The investigation of the prevalence of antibodies against Chlamydia was further pursued and included $430 \mathrm{HIV}-1$ carriers, of which $64.2 \%$ showed positive results. Of great relevance was the finding of $12.6 \%$ with IgM antibodies, demonstrating the presence of a recent or ongoing infection. A sample of positive persons showed seroreactivity by MIF only to C. trachomatis serotypes [54]. These prevalence rates are compatible with the wide spread presented by $C$. trachomatis among population groups seeking diagnosis of STIs $[9,174]$. The high prevalence of antibodies in a group who should be exerting basic STI preventive measures is a worrying matter, including the continuing risk behavior of sexual transmission of infectious agents. Although C. trachomatis infection is treatable, its clinical and laboratory diagnosis are not commonly performed, since most of the carriers of the infection are asymptomatic. Risk behaviors found were anal sex and unprotected sex with more than one partner per week. Such variables are also commonly associated with other STIs as well [35,155,175-178].

One of the epidemiologically interesting ecosystems in the Brazilian Amazon is the Marajó Archipelago, which has a low socioeconomic and education level and poor sanitary conditions that facilitate the spread of STIs. The difficulties in traveling within the archipelago and the distance from urban centers have resulted in social, political and economic isolation and, consequently, poor access to health, which contributes to increases in the disparities that affect the communities inhabiting the archipelago. A prevalence of antibodies against $C$. trachomatis of $30.9 \%$ was found in 1,217 people living in four municipalities located from north to south of the archipelago (Chaves, Anajás, Portel and São Sebastião da Boa Vista), with 6.7\% showing evidence of recent or ongoing infection (presence of IgM antibodies) [157].

A sample of 393 women was investigated for the presence of cervical infection and $4.1 \%$ showed infections with genotypes D, E, F, Ia, J and B, commonly found genotypes in eye infections [13]. It should be noted that seroreactivity specific to serotypes $B$ and Ba had already been detected in other locations in the Brazilian Amazon in the general population [179]. The percentage of people with active genital infection was also compatible with the frequency of those showing IgM antibodies against the bacterium [157].

Social (illiteracy and poverty) and behavioral (alcohol use, multiple sexual partners) variables continue to be important for the spread not only of $C$. trachomatis, but also of other STIs investigated [157]. The most relevant barrier for community development is the low educational level, and seroepidemiological investigations become essential to show the inability to control the spread of STIs $[35,101,155]$. Only a small number of persons have enough information to develop more complex activities, as well as read and understanding disease prevention measures. As a repetitive cycle, the Marajó Archipelago continues to be one of the most vulnerable regions in the state of Para $[180,181]$, where sometimes the family income does not exceed half the minimum wage [157].

Another important manifestation of $C$. trachomatis that cannot be omitted from this review is the presence of trachoma, a neglected disease that affects vulnerable populations and is a major cause of blindness by infectious agents [182]. Signs of active or inactive trachoma have been reported in 33\% of the inhabitants of the Brazilian Amazon for more than 40 years [183]. Investigations by the VL showed that serotypes associated with trachoma were commonly found in several geographical areas $[9,10,157,179]$ and serotype $A$, that used to have its geographical distribution limited to the Middle East and North Africa, was also detected in the Brazilian Amazon for the first time in a semi-isolated community [179]. This was probably introduced through contemporary human migrations [184].

From the serological point of view, it was possible to show in the Marajó Archipelago the extent of the spread of $C$. trachomatis and its serotypes [179]. Genotype B was also found among cervical specimens, which was also observed outside the country [185]. The finding of $C$. trachomatis serotypes/genotypes associated with trachoma came to confirm the need for disease surveillance in the archipelago [186,187]. In an initiative to eliminate trachoma, educational work was carried using the surgery, antibiotics, facial hygiene and education for better habits (SAFE) strategy after the diagnosis of cases. After eight years of follow-up, 
a marked reduction in the disease [187] and the vectors of transmission associated with poor hygiene was observed. The study proved that ocular transmission of $C$. trachomatis in areas with a low human development index needs public policies directed to the region and must include routine examination, immediate treatment, recognition of the associated risk factors and education campaigns in health with accessible language and adaptation to the local population, in addition to a continued investment in school education $[157,187,188]$.

In the evolution of the investigation of $C$. trachomatis, as a relevant STI agent, and eye infections, experimental research focused on its role (along with C. pneumoniae) in the etiology of heart disease. The first approach was the demonstration of specific antibodies to $C$. trachomatis among patients with heart disease treated at a university hospital, with a frequency equal to or greater than that of the urban population in general [179]. Subsequent investigation showed the participation of $C$. trachomatis among patients with coronary artery disease with indication for coronary artery by-pass graft and patients with heart valve disease with indication for valve prosthesis implantation (mitral or aortic).

The multiplication of infectious agents may be the etiology of the chronic inflammation observed in the arterial wall of patients with atherosclerosis [189-191], and C. pneumoniae is one of the main agents hitherto demonstrated. C. trachomatis was detected in situ in $7.4 \%$ of the samples tested for the cryptic plasmid with four samples from the aorta and two from the mitral valve [14], and the in situ presence of $C$. trachomatis antigen by means of immunohistochemistry, in samples of aorta, valves and atheromatous plaque was demonstrated [12]. It should be stressed that genetic polymorphisms of proinflammatory cytokines and their participation in the microenvironment of the vascular and cardiac system have also been investigated and showed an intense local and systemic inflammatory reaction among the investigated patients $[12,14,192]$

\section{Concluding Remarks}

The Amazon region of Brazil is the largest area of the country, but the region is usually overlooked when control of sexually transmitted infectious agents is considered within health programs. The Virus Laboratory of the Federal University of Pará has maintained a continuous investigation of STIs since the second half of the 1980s, including descriptive and molecular epidemiological studies of HIV-1, HTLV-1/2, HBV, HPV, T. pallidum and C. trachomatis. The initial seroprevalence studies evolved for two or three decades, which helped to show the variations in the occurrence of the agents throughout the years and the urgent need to implement health services to most of the population groups. New outcomes of disease were investigated among urban, non-urban and more vulnerable population groups (FSWs, MSM, quilombolas and indigenous communities). The introduction of molecular biology techniques was useful to detect the occurrence and dissemination of genotypes and new strains and their association in the progression of disease with the numerous polymorphisms of the immunological and the inflammatory responses of the host.

Observing the enormous input of data, however, shows that there are still several gaps in the knowledge produced in the last 30 years and it is important to point out new directions for future investigations using sexually transmitted infectious agents as important models of human pathogens.

Author Contributions: L.F.A.M. and R.I. designed the main subject of the review. All authors wrote, read and discussed the first draft of the manuscript content and illustrations. L.F.A.M., R.I., M.d.O.G.I., A.C.R.V., I.M.V.C.-V., M.A.F.Q., R.R.d.S.F. and A.B.O.-F. wrote the final draft. All authors have read and agreed with the final version of the manuscript.

Funding: R.I. (\#312979/2018-5) and A.C.R.V. (\#301869/2017-0) are CNPq (Conselho Nacional de Desenvolvimento Científico e Tecnológico) grantees.

Institutional Review Board Statement: The Virus Laboratory reviewed the results of studies conducted according to the guidelines of the Declaration of Helsinki, and they were all approved by an Institutional Review Board from different institutions, accordingly. 
Informed Consent Statement: Informed consent was obtained from all subjects involved in the several different studies conducted by the Virus Laboratory.

Data Availability Statement: Not applicable.

Acknowledgments: The Virus Laboratory of the Universidade Federal do Pará are deeply indebted to all the persons who took part in the reported results presented in the manuscript, as they were the principal participants who helped the construction of the information bulk which, in turn, is improving the quality of their lives and helping saving lives in the Amazon region of Brazil. The laboratory is profoundly grateful to all the funding agencies which helped us to produce the information since the 1980 s to the present time.

Conflicts of Interest: The authors declare no conflict of interest. The funders had no role in the design of the study; in the collection, analyses, or interpretation of data; in the writing of the manuscript; or in the decision to publish the results.

\section{References}

1. Instituto Brasileiro de Geografia e Estatistica-IBGE. Índice de Desenvolvimento Humano-IDH. 2010. Available online: https: / / cidades.ibge.gov.br/brasil/pa/pesquisa/37/3025530/01/21 (accessed on 2 February 2021).

2. World Health Organization (WHO). Report on Global Sexually Transmitted Infection Surveillance. 2018. Available online: https:/ / www.who.int/reproductivehealth/publications/stis-surveillance-2018/en/ (accessed on 1 March 2021).

3. European Centre for Disease Prevention and Control-ECDPC. Geographical Distribution of Areas with a High Prevalence of HTLV-1 Infection, Technical Report. 2015. Available online: https://www.ecdc.europa.eu/en/publications-data/geographicaldistribution-areas-high-prevalence-htlv-1-infection. (accessed on 28 February 2021).

4. World Health Organization. Global Health Sector Strategies on Sexually Transmitted Infections, 2016-2021. Geneva: World Health Organization. 2016. Available online: http:/ / www.who.int/reproductivehealth/publications/rtis/ghss-stis/en/ (accessed on 20 February 2021).

5. Rowley, J.; Vander Hoorn, S.; Korenromp, E.; Low, N.; Unemo, M.; Abu-Raddad, L.J.; Chico, R.M.; Smolak, A.; Newman, L.; Gottlieb, S.; et al. Chlamydia, gonorrhoea, trichomoniasis and syphilis: Global prevalence and incidence estimates, 2016. Bull World Health Org. 2019, 97, 548-562. [CrossRef] [PubMed]

6. Mitsui, M.; Tsukahara, Y. STD and mother to child transmission. Nihon Rinsho. 2009, 67, 177-184. [PubMed]

7. Unemo, M.; Bradshaw, C.S.; Hocking, J.S.; de Vries, H.J.C.; Francis, S.C.; Mabey, D.; Marrazzo, J.M.; Sonder, G.J.B.; Schwebke, J.R.; Hoornenborg, E.; et al. Sexually transmitted infections: Challenges ahead. Lancet Infect. Dis. 2017, 17, e235-e279. [CrossRef]

8. Korenromp, E.L.; Wi, T.; Resch, S.; Stover, J.; Broutet, N. Costing of national STI program implementation for the global STI control strategy for the health sector, 2016-2021. PLOS ONE 2017, 12, e0170773. [CrossRef]

9. Ishak, M.O.; Ishak, R.; Cruz, A.C.; Santos, D.E.; Salgado, U. Chlamydial infection in the Amazon region of Brazil. Trans. R Soc. Trop. Med. Hyg. 1993, 87, 60-62. [CrossRef]

10. Ishak, M.O.; Ishak, R. Chlamydia infection impact among native Indian groups of the Brazilian Amazon region. Cad. Saude. Publ. 2001, 17, 385-396. [CrossRef]

11. Ferreira, G.R.V.; Tomioka, R.B.; Queiroz, L.B.; Kozu, K.; Aikawa, N.E.; Sallum, A.M.E.; Serafini, P.; Tacla, M.; Baracat, E.C.; Pereira, R.M.R.; et al. Lower genital tract infections in young female juvenile idiopathic arthritis patients. Adv. Rheumatol. $2019,15,50$. [CrossRef]

12. Freitas, L.S.; Almeida, N.C.C.; Freitas Queiroz, M.A.; Zaninotto, M.M.; Fuzii, H.T.; Ribeiro-Silva, A.; Vallinoto, A.C.; Ishak, M.O.; Quaresma, J.A.; Ishak, R. In situ detection of Chlamydia pneumoniae, C. trachomatis, and cytokines among cardiovascular diseased patients from the Amazon region of Brazil. Infect. Drug Resist. 2017, 10, 109-114. [CrossRef]

13. dos Santos, L.M.; Vieira, M.R.M.D.S.; Oliveira, J.F.G.; Trindade, J.Q.; Brasiliense, D.M.; Ferrari, S.F.; Tsutsumi, M.Y.; Fuzii, H.T.; Sousa Junior, E.C.; Ishikawa, E.A.Y.; et al. High prevalence of sexual Chlamydia trachomatis infection in young women from Marajo Island, in the Brazilian Amazon. PLoS ONE 2018, 13, e0207853. [CrossRef]

14. Almeida, N.C.C.; Queiroz, M.A.F.; Lima, S.S.; Brasil Costa, I.; Ayin Fossa, M.A.; Vallinoto, A.C.R.; Ishak, M.O.G.; Ishak, R. Association of chlamydia trachomatis, C. pneumoniae, and IL-6 and IL-8 gene alterations with heart diseases. Front. Immunol. 2019, 1, 87. [CrossRef]

15. GBD 2013 Mortality and Causes of Death Collaborators. Global, regional, and national age-sex specific all-cause and cause-specific mortality for 240 causes of death, 1990-2013: A systematic analysis for the global burden of disease study 2013. Lancet 2015, 385, 117-171. [CrossRef]

16. Deeks, S.G.; Overbaugh, J.; Phillips, A.; Buchbinder, S. HIV infection. Nat. Rev. Dis. Prim. 2015, 1, 15035. [CrossRef]

17. Bradley, H.; Hogan, V.; Agnew-Brune, C.; Armstrong, J.; Broussard, D.; Buchacz, K.; Burton, K.; Cope, S.; Dawson, E.; De La Garza, G.; et al. Increased HIV diagnoses in West Virginia counties highly vulnerable to rapid HIV dissemination through injection drug use: A cautionary tale. Ann. Epidemiol. 2019, 34, 12-17. [CrossRef] 
18. Coelho, L.E.; Torres, T.S.; Veloso, V.G.; Grinsztejn, B.; Jalil, E.M.; Wilson, E.C.; McFarland, W. The prevalence of HIV among men who have sex with men (MSM) and young MSM in Latin America and the Caribbean: A systematic review. AIDS Behav. 2021. [CrossRef] [PubMed]

19. Arias Garcia, S.; Chen, J.; Calleja, J.G.; Sabin, K.; Ogbuanu, C.; Lowrance, D.; Zhao, J. Availability and quality of surveillance and survey data on HIV prevalence among sex workers, men who have sex with men, people who inject drugs, and transgender women in low- and middle-income countries: Review of available data (2001-2017). JMIR Publ. Health Surveill. 2020, 6, e21688. [CrossRef] [PubMed]

20. Haase, A.T. Targeting early infection to prevent HIV-1 mucosal transmission. Nature 2010, 464, 217-223. [CrossRef] [PubMed]

21. Joint United Nations Programme on HIV/AIDS-UNAIDS. UNAIDS Data Reference, 2nd ed. 2020. Available online: https: //www.unaids.org/en/resources/documents/2020/unaids-data (accessed on 13 February 2021).

22. Brasil. Boletim Epidemiológico Anual de HIV/AIDS. 2020. Available online: http://www.aids.gov.br/pt-br/pub/2020/boletimepidemiologico-hivaids-2020 (accessed on 8 February 2021).

23. Hemelaar, J.; Elangovan, R.; Yun, J.; Dickson-Tetteh, L.; Fleminger, I.; Kirtley, S.; Williams, B.; Gouws-Williams, E.; Ghys, P.D.; WHO-UNAIDS Network for HIV Isolation Characterisation. Global and Regional Molecular Epidemiology of HIV-1, 1990-2015: A Systematic Review, Global Survey, and Trend Analysis. Lancet Infect. Dis. 2019, 19, 143-155. [CrossRef]

24. Tanaka, T.S.O.; Leite, T.F.; Freitas, S.Z.; Cesar, G.A.; de Rezende, G.R.; Lindenberg, A.S.C.; Guimarães, M.L.; Motta-Castro, A.R. HIV-1 Molecular epidemiology, transmission clusters and transmitted drug resistance mutations in central Brazil. Front. Microbiol. 2019, 10, 20. [CrossRef] [PubMed]

25. da Costa, C.P.; Rodrigues, J.K.F.; de Morais, V.M.S.; de Andrade, C.A.D.N.; Neves, P.A.F.; Lima, K. HIV-1 subtype frequency in Northeast Brazil: A systematic review and meta-analysis. J. Med. Virol. 2020. [CrossRef] [PubMed]

26. Bahls, L.D.; Canezin, P.H.; Reiche, E.M.V.; Fernandez, J.C.C.; Dias, J.R.C.; Meneguetti, V.A.F.; Ueda, L.T.; Bertolini, D.A. Moderate prevalence of HIV-1 transmitted drug resistance mutations in southern Brazil. AIDS Res. Ther. 2019, 16, 4. [CrossRef] [PubMed]

27. Machado, L.F.; Ishak, M.O.; Vallinoto, A.C.; Lemos, J.A.; Azevedo, V.N.; Moreira, M.R.; Souza, M.I.; Fernandes, L.M.; Souza, L.L.; Ishak, R. Molecular epidemiology of HIV type 1 in northern Brazil: Identification of subtypes C and D and the introduction of CRF02_AG in the Amazon region of Brazil. AIDS Res. Hum. Retrovir. 2009, 25, 961-966. [CrossRef] [PubMed]

28. Ishak, R.; Ishak, M.O.G.; Tsiquaye, K.; Cardoso, D.D.P. Soroepidemiologia retrospectiva dO HIV-1. Rev. Inst. Med. Trop. São Paulo 1989, 31, 80-83. [CrossRef] [PubMed]

29. Linhares, A.C.; Mello, W.A. The prevalence of HIV-antibody in a gold mining camp in the Amazon region as a guide to the date of entry of AIDS into Brazil: The future importance of such communities as "distribution centres". Rev. Inst. Med. Trop. Sao Paulo 1989, 31, 29. [CrossRef]

30. Bastos, F.I.; Barcellos, C. The social geography of AIDS in Brazil. Rev. Saude Publ. 1995, 29, 52-62. [CrossRef] [PubMed]

31. Azevedo, V.N.; Ishak, M.O.G.; Murta, R.; Saraiva, J.C.P. Avaliaçåo de um teste de aglutinaçåo de partículas de gelatina para a detecçåo de anticorpos anti-HIV-1 / Evaluation of the gelatin particle agglutination test for the detection of anti-HIV-1 antibodies. Rev. Bras. Patol. Clín. 1992, 28, 71-74.

32. Machado, L.F.; Vallinoto, A.C.; Souza, M.I.; Azevedo, V.N.; Ishak, M.O.; Ishak, R. Serological and molecular typing of HIV type 1 infection in the Tiriyo tribe, a native Indian community of the Amazon region of Brazil. AIDS Res. Hum. Retrovir. 2006, 22, 1267-1270. [CrossRef]

33. Shindo, N.; Alcantara, L.C.; Van Dooren, S.; Salemi, M.; Costa, M.C.; Kashima, S.; Covas, D.T.; Teva, A.; Pellegrini, M.; Brito, I.; et al. Human retroviruses (HIV and HTLV) in Brazilian Indians: Seroepidemiological study and molecular epidemiology of HTLV type 2 isolates. AIDS Res. Hum. Retrovir. 2002, 18, 71-77. [CrossRef]

34. Benzaken, A.S.; Sabidó, M.; Brito, I.; Bermúdez, X.P.D.; Benzaken, N.S.; Galbán, E.; Peeling, R.W.; Mabey, D. HIV and syphilis in the context of community vulnerability among indigenous people in the Brazilian Amazon. Int. J. Equity Health. 2017, 16, 92. [CrossRef]

35. Vallinoto, A.C.; Aguiar, S.; Sá, K.G.; Freitas, F.B.; Ferreira, G.; Lima, S.S.; Machado, L.F.; Cayres-Vallinoto, I.; Ishak, M.; Ishak, R. Prevalence and risk behaviour for human immunodeficiency virus 1 infection in Marajo Island, Northern Brazil. Ann. Hum. Biol. 2016, 43, 397-404. [CrossRef]

36. Macêdo, O.; Freitas, F.B.; dos Reis, R.M.; Bensabath, G.; Nunes, H.M.; Siqueira, J.A.M.; Gabbay, Y.B. Prevalence and epidemiological characteristics of human immunodeficiency virus-1 infection in an iron mining area with intense migratory flow in Para State, Brazilian amazon, 2005-2014. Braz. J. Microbiol. 2020, 51, 1737-1745. [CrossRef]

37. Guerra, A.B.; Siravenha, L.Q.; Laurentino, R.V.; Feitosa, R.N.M.; Azevedo, V.N.; Vallinoto, A.C.R.; Ishak, R.; Machado, L.F.A. Seroprevalence of HIV, HTLV, CMV, HBV and rubella virus infections in pregnant adolescents who received care in the city of Belem, Para, Northern Brazil. BMC Pregnancy Childbirth 2018, 18, 169. [CrossRef] [PubMed]

38. Machado Filho, A.C.; Sardinha, J.F.; Ponte, R.L.; Costa, E.P.; da Silva, S.S.; Martinez-Espinosa, F.E. Prevalence of infection for HIV, HTLV, HBV and of syphilis and chlamydia in pregnant women in a tertiary health unit in the western Brazilian Amazon region. Rev. Bras. Ginecol. Obstet. 2010, 32, 176-183. [PubMed]

39. de Souza, R.L.; Pereira, M.V.S.; da Silva, R.M.; Sales, J.B.L.; Gardunho, D.C.L.; Monteiro, J.C.; Siravenha, L.Q.; da Luz, A.L.B.; Fonseca, R.R.S.; Oliveira-Filho, A.B.; et al. Molecular epidemiology of HIV-1 and HTLV-1/2 among female sex workers in four cities in the state of Para, Northern Brazil. Front. Microbiol. 2020, 11, 602664. [CrossRef] 
40. da Costa, L.M.; Raiol, N.C.; Lisboa, B.L.A.; Frade, P.C.R.; Blandtt, L.D.S.; Silva-Oliveira, G.C.; Machado, L.F.A.; Martins, L.C.; Oliveira-Filho, A.B. Prevalence and risk factors for human immunodeficiency virus infection among female sex workers: Distinct offers of sexual services in a municipality of the Brazilian Amazon. AIDS Res. Hum. Retrovir. 2019, 35, 826-832. [CrossRef]

41. Oliveira-Filho, A.B.; Silva, F.Q.; Santos, F.J.A.; Cardoso, Y.M.N.; Di Miceli, J.F.F.; Resque, R.L.; Silva-Oliveira, G.C.; Martins, L.C.; Pinheiro, L.M.L.; Machado, L.F.A.; et al. Prevalence and risk factors for HIV-1 infection in people who use illicit drugs in northern Brazil. Trans. R. Soc. Trop. Med. Hyg. 2020, 114, 213-221. [CrossRef]

42. de Oliveira, E.H.; Verde, R.M.C.L.; Oliveira Filho, A.B.; Soares, L.F.; Silva Júnior, F.T.D.S.; Queiroz, M.A.F.; Vallinoto, A.C.R. HIV / AIDS in the elderly: Epidemiological impact and associated risk factors in the State of Piauí, Brazil. Res. Soc. Dev. 2020, 9, e460985906. [CrossRef]

43. Vallinoto, A.C.; Azevedo, V.N.; Santos, D.E.; Caniceiro, S.; Mesquita, F.C.; Hall, W.W.; Ishak, M.O.; Ishak, R. Serological evidence of HTLV-I and HTLV-II coinfections in HIV-1 positive patients in Belem, state of Para, Brazil. Mem. Inst. Oswaldo Cruz. 1998, 93, 407-409. [CrossRef]

44. Brites, C.; Harrington, W., Jr.; Pedroso, C.; Netto, E.M.; Badaró, R. Epidemiological characteristics of HTLV-I and II coinfection in Brazilian subjects infected by HIV-1. Braz. J. Infect. Dis. 1997, 1, $42-47$.

45. Laurentino, R.V.; Lopes, I.G.; Azevedo, V.N.; Machado, L.F.; Moreira, M.R.; Lobato, L.; Ishak, M.O.; Ishak, R.; Vallinoto, A.C. Molecular characterization of human T-cell lymphotropic virus coinfecting human immunodeficiency virus 1 infected patients in the Amazon region of Brazil. Mem. Inst. Oswaldo Cruz. 2005, 100, 371-376. [CrossRef]

46. Alencar, S.P.; Souza, M.C.; Fonseca, R.R.S.; Menezes, C.R.; Azevedo, V.N.; Ribeiro, A.L.R.; Lima, S.S.; Laurentino, R.V.; Barbosa, M.D.A.A.P.; Freitas, F.B.; et al. Prevalence and molecular epidemiology of human T-Lymphotropic virus (HTLV) infection in people living with HIV / AIDS in the Pará State, Amazon Region of Brazil. Front. Microbiol. 2020, 11, 572381. [CrossRef]

47. de Oliveira, E.H.; Oliveira-Filho, A.B.; Souza, L.A.; da Silva, L.V.; Ishak, M.O.; Ishak, R.; Vallinoto, A.C. Human T-cell lymphotropic virus in patients infected with HIV-1: Molecular epidemiology and risk factors for transmission in Piaui, Northeastern Brazil. Curr. HIV Res. 2012, 10, 700-707. [CrossRef] [PubMed]

48. Menezes, T.O.; Gillet, L.C.; Menezes, S.A.; Feitosa, R.N.; Ishak, M.O.; Ishak, R.; Marques-da-Silva, S.H.; Vallinoto, A.C. Virulence factors of Candida albicans isolates from the oral cavities of HIV-1-positive patients. Curr. HIV Res. 2013, 11, 304-308. [CrossRef] [PubMed]

49. Jácome-Santos, H.; Amanajás, T.A.; Gomes, S.T.M.; Machado, L.F.A.; Pereira Neto, A.R.L.; Alves Junior, S.M.; Pinheiro, J.J.V.; Alves, B.P.; Amoras-Alves, A.C.B. Epstein-Barr virus (EBV) in periodontal sites of human immunodeficiency virus (HIV)-positive individuals in North Brazil: A cross-sectional study. Quintessence Int. 2020, 51, 18-26. [PubMed]

50. Fonseca, R.R.S.; Alves, A.C.B.A.; Amanajás, T.A.; Nogueira, B.M.L.; Menezes, T.O.A.; Siravenha, L.Q.; Pereira, D.L.A.; Machado, L.F.A.; Gilet, L.C.D.S.; Menezes, S.A.F. Absence of cytomegalovirus in gingivitis and chronic periodontitis in HIV-1 patients in Northern Brazil. Rev. Soc. Bras. Med. Trop. 2018, 51, 809-812. [CrossRef] [PubMed]

51. Oliveira, E.H.; Verde, R.M.L.; Pinheiro, L.M.; Benchimol, M.G.; Aragão, A.L.; Lemos, J.A.; Oliveira-Filho, A.B.; Vallinoto, A.C HBV infection in HIV-infected subjects in the state of Piauí, Northeast Brazi. Arch. Virol. 2014, 159, 1193-1197. [CrossRef] [PubMed]

52. Lobo, M.N.; Barata, J.L.S.; de Jesus, R.F.; de Oliveira, J.B.G.; Neto, P.L.F.; Ribeiro, A.L.R.; Machado, L.F.A. Prevalence of HCV infection in newly-diagnosed HIV patients in the City of Belém.; Pará.; Brazil: A Preliminary Report. Int. J. Curr. Microbiol. App. Sci. 2018, 7, 3266-3270. [CrossRef]

53. Rodrigues, L.L.S.; Ishak, R.; Vallinoto, A.C.R.; Feitosa, R.M.F.; Azevedo, V.N.; Silvestre, R.; Laurentino, R.V.; Monteiro, J.; Silva, A.; Machado, L.F.A. Prevalence and genotype diversity of anal HPV infection among HIV-infected women in Belém.; Pará.; North of Brazil. International. J. Microbiol. Res. 2018, 10, 993-996.

54. Almeida, N.C.C.; Madeira, L.D.P.S.; Hermes, R.B.; Chaves, M.H.; Machado, L.F.A.; Vallinoto, A.C.R.; Ishak, M.O.G.; Ishak, R. Frequência de Chlamydia trachomatis, Chlamydia pneumoniae e Treponema pallidum em portadores do vírus da imunodeficiência humana 1 (HIV-1), no estado do pará. Ver Educ. Sal. 2015, 1, 84-98.

55. Neto, P.L.F.; Fernandes, É.M.F.; do Nascimento, M.R.O.; Paes, R.P.; Irias, S.D.F.; Avelino, M.E.S.; Torres, M.K.S.; Azevedo, V.N.; Feitosa, R.N.M.; Oliveira-Filho, A.B.; et al. Syphilis among newly diagnosed therapy-naive HIV patients in Belém.; Pará.; Amazon region of Brazil. AIDS Res. Hum. Retrovir. 2019, 35, 511-512. [CrossRef]

56. Cayres-Vallinoto, I.M.; Vallinoto, A.C.; Pena, G.P.; Azevedo, V.N.; Machado, L.F.; Ishak, M.D.O.G.; Ishak, R. JC virus/human immunodeficiency virus 1 co-infection in the Brazilian Amazonian region. Braz. J. Infect. Dis. 2016, 20, 360-364. [CrossRef]

57. de Miranda, B.K.B.; de Sá, K.S.G.; da Silva, A.N.R.; Feitosa, R.N.M.; Cayres-Vallinoto, I.M.V.; Ishak, R.; Vallinoto, A.C.R. GBVC/HIV-1 coinfection is associated with low HIV-1 viral load and high CD4+ T lymphocyte count. Arch. Virol. 2017, 162, 3431-3438. [CrossRef] [PubMed]

58. Ferreira, A.S.; Cardoso, L.P.; Stefani, M.M. Moderate prevalence of transmitted drug resistance and high HIV-1 genetic diversity in patients from Mato Grosso State, Central Western Brazil. J. Med. Virol. 2011, 83, 1301-1307. [CrossRef]

59. Carvalho, B.C.; Cardoso, L.P.; Damasceno, S.; Stefani, M.M. Moderate prevalence of transmitted drug resistance and interiorization of HIV type 1 subtype C in the inland North State of Tocantins.; Brazil. AIDS Res. Hum. Retrovir. 2011, 27, 1081-1087. [CrossRef]

60. Cunha, L.K.; Kashima, S.; Amarante, M.F.; Haddad, R.; Rodrigues, E.S.; Silva, K.L.; Lima, T.A.; Castro, D.B.; Brito, F.C.; Almeida, E.G.; et al. Distribution of human immunodeficiency virus type 1 subtypes in the State of Amazonas, Brazil, and subtype C identification. Braz. J. Med. Biol. Res. 2012, 45, 104-112. [CrossRef] [PubMed] 
61. Crispim, M.A.E.; Reis, M.N.D.G.; Abrahim, C.; Kiesslich, D.; Fraiji, N.; Bello, G.; Stefani, M.M.A. Homogenous HIV-1 subtype B from the Brazilian Amazon with infrequent diverse BF1 recombinants, subtypes F1 and C among blood donors. PLoS ONE 2019, 14, e0221151. [CrossRef] [PubMed]

62. Machado, L.F.; Costa, I.B.; Folha, M.N.; da Luz, A.L.; Vallinoto, A.C.; Ishak, R.; Ishak, M.O. Lower genetic variability of HIV-1 and antiretroviral drug resistance in pregnant women from the state of Para, Brazil. BMC Infect. Dis. 2017, 17, 270. [CrossRef] [PubMed]

63. Irias, S.D.F.; Avelino, M.E.S.; Torres, M.K.S.; Santos, M.B.; Queiroz, M.A.F.; Pereira, D.L.A.; Burlamaqui, T.C.T.; Freitas, F.B.; Vallinoto, A.C.R.; Azevedo, V.N.; et al. Low HIV-1 Subtypes diversity based on the pol gene and transmitted drug resistance in antiretroviral-naive patients from Belém, Pará, Amazon Region of Brazil. Int. J. Microbiol. Res. 2018, 10, $1406-1410$.

64. Torres, M.K.S.; Avelino, M.E.S.; Irias, S.F.; Barbosa, M.S.; Pereira, D.L.A.; Lima, A.B.F.; Lemos, P.S.; Lima, C.P.S.; Oliveira, R.R.M.; Frânces, R.S.K.; et al. Low prevalence of HIV-1 integrase resistance among antiretroviral-naive patients newly diagnosed with HIV-1 from Belem, Para, Amazon Region of Brazil. AIDS Res. Hum. Retrovir. 2020, 36, 97-98. [CrossRef]

65. Irias, S.D.F.; Torres, M.K.S.; Avelino, M.E.S.; Santos, M.B.; Queiroz, M.A.F.; Freitas, F.B.; Azevedo, V.N.; Feitosa, R.N.M.; Vallinoto, A.C.R.; Machado, L.F.A. HIV-1 Transmitted drug resistance mutations in recently diagnosed antiretroviral-naive patients in Belem, Para, Northern Brazil. AIDS Res. Hum. Retrovir. 2019, 35, 121-122. [CrossRef]

66. Vallinoto, A.C.; Menezes-Costa, M.R.; Alves, A.E.; Machado, L.F.; de Azevedo, V.N.; Souza, L.L.; Ishak, M.D.O.G.; Ishak, R. Mannose-binding lectin gene polymorphism and its impact on human immunodeficiency virus 1 infection. Mol. Immunol. 2006, 43, 1358-1362. [CrossRef]

67. Vallinoto, A.C.; Muto, N.A.; Alves, A.E.; Machado, L.F.; Azevedo, V.N.; Souza, L.L.; Ishak, M.O.; Ishak, R. Characterization of polymorphisms in the mannose-binding lectin gene promoter among human immunodeficiency virus 1 infected subjects. Mem. Inst. Oswaldo Cruz. 2008, 103, 645-649. [CrossRef] [PubMed]

68. Carvalhaes, F.A.P.L.; Cardoso, G.L.; Vallinoto, A.C.R.; Machado, L.F.A.; Ishak, M.O.G.; Ishak, R.; Guerreiro, J.F. Frequencies of CCR5-D32.; CCR2-64I and SDF1-3'A mutations in human immunodeficiency virus (HIV) seropositive subjects and seronegative individuals from the state of Pará in Brazilian Amazonia. Genetics Molec. Biol. 2005, 28, 665-669. [CrossRef]

69. Loureiro dos Reis, M.M.; Queiroz, M.A.F.; da Silva, B.C.M.; da Silva Duarte, A.J.; Casseb, J.; Arganaraz, G.A.; Vallinoto, A.C.R.; Argañaraz, E.R. IL6 and FAS/FASL gene polymorphisms may be associated with disease progression in HIV-1-positive ethnically mixed patients. J. Med. Virol. 2020, 92, 1148-1157. [CrossRef] [PubMed]

70. Hermes, R.B.; Santana, B.B.; Lima, S.S.; Neris Martins Feitosa, R.; de Oliveira Guimarães Ishak, M.; Ishak, R.; Vallinoto, A.C. FAS -670 A/G polymorphism may be associated with the depletion of CD4(+) T lymphocytes in HIV-1 infection. Hum. Immunol. 2015, 76, 742-746. [CrossRef] [PubMed]

71. Freitas, F.B.; Lima, S.S.; Feitosa, R.N.; Azevedo, V.N.; Ishak, M.D.O.G.; Ishak, R.; Vallinoto, A.C. Polymorphisms in the IFN $\gamma$, IL-10, and TGF $\beta$ genes may be associated with HIV-1 infection. Dis. Mark. 2015, 2015, 248571.

72. Queiroz, M.A.F.; Laurentino, R.V.; da Silva Graça Amoras, E.; Araújo, M.S.M.; Gomes, S.T.M.; Lima, S.S.; Vallinoto, A.C.R.; de Oliveira Guimarães Ishak, M.; Ishak, R.; Machado, L.F.A. The CYP2B6 G516T polymorphism influences CD4+ T-cell counts in HIV-positive patients receiving antiretroviral therapy in an ethnically diverse region of the Amazon. Int. J. Infect. Dis. 2017, 55, 4-10. [CrossRef]

73. Gomes, S.T.M.; Gomes, É.R.; Dos Santos, M.B.; Lima, S.S.; Queiroz, M.A.F.; Machado, L.F.A.; Cayres-Vallinoto, I.M.V.; Vallinoto, A.C.R.; de O Guimarães Ishak, M.; Ishak, R. Immunological and virological characterization of HIV-1 viremia controllers in the North Region of Brazil. BMC Infect. Dis. 2017, 17, 381. [CrossRef] [PubMed]

74. Gomes, S.T.M.; da Silva Graça Amoras, E.; Gomes, E.R.; Queiroz, M.A.F.; Júnior, E.C.S.; de Vasconcelos Massafra, J.M.; da Silva Lemos, P.; Júnior, J.L.V.; Ishak, R.; Vallinoto, A.C.R. Immune escape mutations in HIV-1 controllers in the Brazilian Amazon region. BMC Infect. Dis. 2020, 20, 546. [CrossRef] [PubMed]

75. Martinez, M.P.; Al-Saleem, J.; Green, P.L. Comparative virology of HTLV-1 and HTLV-2. Retrovirology 2019, 16, 21. [CrossRef]

76. Schierhout, G.; McGregor, S.; Gessain, A.; Einsiedel, L.; Martinello, M.; Kaldor, J. Association between HTLV-1 infection and adverse health outcomes: A systematic review and meta-analysis of epidemiological studies. Lancet Infect. Dis. 2020, 20, 133-143. [CrossRef]

77. Ishak, R.; Guimarães Ishak, M.O.; Azevedo, V.N.; Machado, L.F.A.; Vallinoto, I.M.C.; Queiroz, M.A.F.; Costa, G.L.C.; Guerreiro, J.F.; Vallinoto, A.C.R. HTLV in South America: Origins of a silent ancient human infection. Virus Evol. 2020, 6, veaa053. [CrossRef]

78. Futsch, N.; Mahieux, R.; Dutartre, H. HTLV-1, the other pathogenic yet neglected human retrovirus: From transmission to therapeutic treatment. Viruses 2017, 10, 1. [CrossRef] [PubMed]

79. Ishak, R.; Harrington, W.J., Jr.; Azevedo, V.N.; Eiraku, N.; Ishak, M.O.; Guerreiro, J.F.; Santos, S.B.; Kubo, T.; Monken, C.; Alexander, S.; et al. Identification of human T cell lymphotropic virus type IIa infection in the Kayapo, an indigenous population of Brazil. AIDS Res. Hum. Retrovir. 1995, 11, 813-821. [CrossRef] [PubMed]

80. Ishak, R.; Vallinoto, A.C.; Azevedo, V.N.; Lewis, M.; Hall, W.W.; Guimarães Ishak, M.O. Molecular evidence of mother-to-child transmission of HTLV-IIc in the Kararao Village (Kayapo) in the Amazon region of Brazil. Rev. Soc. Bras. Med. Trop. 2001, 34, 519-525. [CrossRef]

81. Silva, K.L.T. Caracterização Sorológica e Molecular da Infecção Pelo Vírus Linfotrópico de Células T Humanas 1 e 2 (HTLV-1 e HTLV-2) em Três Comunidades Indígenas da Amazônia Brasileira. Master's Thesis, Universidade Federal do Pará, Pará, Brasil, 2007. 
82. Braço, I.L.J.; de Sá, K.S.G.; Waqasi, M.; Queiroz, M.A.F.; da Silva, A.N.R.; Cayres-Vallinoto, I.M.V.; Lima, S.S.; de Oliveira Guimarães Ishak, M.; Ishak, R.; Guerreiro, J.F.; et al. High prevalence of human T-lymphotropic virus 2 (HTLV-2) infection in villages of the Xikrin tribe (Kayapo).; Brazilian Amazon region. BMC Infect. Dis. 2019, 19, 459. [CrossRef] [PubMed]

83. Vallinoto, A.C.; Ishak, M.O.; Azevedo, V.N.; Vicente, A.C.; Otsuki, K.; Hall, W.W.; Ishak, R. Molecular epidemiology of human T-lymphotropic virus type II infection in Amerindian and urban populations of the Amazon region of Brazil. Hum. Biol. 2002, 74, 633-644. [CrossRef] [PubMed]

84. Ishak, R.; Vallinoto, A.C.; Azevedo, V.N.; Ishak, M.D. Epidemiological aspects of retrovirus (HTLV) infection among Indian populations in the Amazon Region of Brazil. Cad. Saude Publ. 2003, 19, 901-914. [CrossRef]

85. Ishak, R.; de Oliveira Guimarães Ishak, M.; Vallinoto, A.C.R. The challenge of describing the epidemiology of HTLV in the Amazon region of Brazil. Retrovirology 2020, 17, 4. [CrossRef]

86. Vallinoto, A.C.R.; Otake, M.I.; Sousa, P.V.N.R.; Lopes, F.T.; Sacuena, E.R.P.; Queiroz, M.A.F.; Costa, G.L.C.; Ishak, M.O.G.; Cayres-Vallinoto, I.M.V.; Guerreiro, J.F.; et al. Isolation of the Arawete and Asurini Indians keeps the tribes free from HTLV infection during 36 years of follow-up. Retrovirology 2019, 16, 27. [CrossRef]

87. Lewis, M.J.; Novoa, P.; Ishak, R.; Ishak, M.; Salemi, M.; Vandamme, A.M.; Kaplan, M.H.; Hall, W.W. Isolation, cloning, and complete nucleotide sequence of a phenotypically distinct Brazilian isolate of human T-lymphotropic virus type II (HTLV-II). Virology 2000, 271, 142-154. [CrossRef]

88. Ishak, R.; Ishak, M.O.; Azevedo, V.N.; Santos, D.E.; Vallinoto, A.C.; Saraiva, J.C.; Crescente, J.A.; Hall, W.W. Detection of HTLV-IIa blood donors in an urban area of the Amazon Region of Brazil (Belém, PA). Rev. Soc. Bras. Med. Trop. 1998, 31, 193-197. [CrossRef] [PubMed]

89. Pontes, G.S.; Ribeiro, H.H.F.; Toro, D.M.; Moura Neto, J.P.; Souza, V.; Almeida, M.E.M.; Nascimento, V.A.D.; Costa, C.A.D.; Naveca, F.G.; Santos, M.; et al. HTLV-2 infection in Manaus.; Brazil: First description of HTLV-2c subtype in an urban area of the Western Amazon region. Rev. Soc. Bras. Med. Trop. 2020, 54, e20200066. [CrossRef] [PubMed]

90. Eiraku, N.; Novoa, P.; da Costa Ferreira, M.; Monken, C.; Ishak, R.; da Costa Ferreira, O.; Zhu, S.W.; Lorenco, R.; Ishak, M.; Azvedo, V.; et al. Identification and characterization of a new and distinct molecular subtype of human T-cell lymphotropic virus type 2. J. Virol. 1996, 70, 1481-1492. [CrossRef]

91. Silva, E.A.; Otsuki, K.; Leite, A.C.; Alamy, A.H.; Sá-Carvalho, D.; Vicente, A.C. HTLV-II infection associated with a chronic neurodegenerative disease: Clinical and molecular analysis. J. Med. Virol. 2002, 66, 253-257. [CrossRef] [PubMed]

92. Catalan-Soares, B.; Barbosa-Stancioli, E.F.; Alcantara, L.C.; Carneiro-Proietti, A.B.; Martins, M.L.; Namen-Lopes, M.S.; GalvãoCastro, B.; Ferreira, C.E.; Costa, M.C.; Pinheiro, S.R.; et al. HTLV-2 horizontal and vertical transmission in a family from a Brazilian urban area: Seroepidemiological, clinical and molecular study. AIDS Res. Hum. Retrovir. 2005, 21, 521-526. [CrossRef] [PubMed]

93. Renner, J.D.; Laurino, J.P.; Menna-Barreto, M.; Schmitt, V.M. Molecular evidence of HTLV-II subtype B among an urban population living in South Brazil. AIDS Res. Hum. Retrovir. 2006, 22, 301-306. [CrossRef] [PubMed]

94. Barreto, F.K.; Rego, F.F.; Fonseca, L.M.; Galvão-Castro-Filho, B.; Araújo, T.H.; Mota-Miranda, A.C.; Monteiro-Cunha, J.P.; Alcantara, L.C. Molecular characterization of the human T cell lymphotropic virus type 2 long terminal repeat region: A discussion about possible influences at viral gene expression. AIDS Res. Hum. Retrovir. 2014, 30, 92-96. [CrossRef]

95. Diop, S.; Calattini, S.; Abah-Dakou, J.; Thiam, D.; Diakhaté, L.; Gessain, A. Seroprevalence and molecular epidemiology of human T-Cell leukemia virus type 1 (HTLV-1) and HTLV-2 in blood donors from Dakar, Senegal. J. Clin. Microbiol. 2006, 44, 1550-1554. [CrossRef]

96. Vallinoto, A.C.; Pontes, G.S.; Muto, N.A.; Lopes, I.G.; Machado, L.F.; Azevedo, V.N.; Carvalhaes, F.A.; Santos, S.E.; Guerreiro, J.F.; Ishak, M.O.; et al. Identification of human T-cell lymphotropic virus infection in a semi-isolated Afro-Brazilian quilombo located in the Marajó Island (Pará, Brazil). Mem. Inst. Oswaldo Cruz. 2006, 101, 103-105. [CrossRef]

97. Santos, S.B.; Porto, A.F.; Muniz, A.L.; Luna, T.; Nascimento, M.C.; Guerreiro, J.B.; Oliveira-Filho, J.; Morgan, D.J.; Carvalho, E.M. Modulation of T cell responses in HTLV-1 carriers and in patients with myelopathy associated with HTLV-1. Neuroimmunomodulation 2006, 13, 145-151. [CrossRef]

98. Oliveira-Filho, A.B.; Araújo, A.P.S.; Souza, A.P.C.; Gomes, C.M.; Silva-Oliveira, G.C.; Martins, L.C.; Fischer, B.; Machado, L.F.A.; Vallinoto, A.C.R.; Ishak, R.; et al. Human T-lymphotropic virus 1 and 2 among people who used illicit drugs in the state of Para, northern Brazil. Sci. Rep. 2019, 9, 14750. [CrossRef]

99. Vallinoto, A.C.; Muto, N.A.; Pontes, G.S.; Machado, L.F.; Azevedo, V.N.; dos Santos, S.E.; Ribeiro-dos-Santos, A.K.; Ishak, M.O.; Ishak, R. Serological and molecular evidence of HTLV-I infection among Japanese immigrants living in the Amazon region of Brazil. Jpn. J. Infect. Dis. 2004, 57, 156-159. [PubMed]

100. Souza, L.A.; Lopes, I.G.; Maia, E.L.; Azevedo, V.N.; Machado, L.F.; Ishak, M.O.; Ishak, R.; Vallinoto, A.C. Molecular characterization of HTLV-1 among patients with tropical spastic paraparesis/HTLV-1 associated myelopathy in Belem, Para. Rev. Soc. Bras. Med. Trop. 2006, 39, 504-506. [CrossRef] [PubMed]

101. de Aguiar, S.A.; de Souza França, S.A.; Santana, B.B.; Santos, M.B.; Freitas, F.B.; Ferreira, G.; Cayres-Vallinoto, I.; Ishak, M.O.G.; Ishak, R.; Vallinoto, A.C.R. Human T-lymphotropic virus 1aA circulation and risk factors for sexually transmitted infections in an Amazon geographic area with lowest human development index (Marajo Island.; Northern Brazil). BMC Infect. Dis. 2017, 17, 758. [CrossRef] 
102. Ma, Y.; Zheng, S.; Wang, N.; Duan, Y.; Sun, X.; Jin, J.; Zang, W.; Li, M.; Wang, Y.; Zhao, G. Epidemiological analysis of HTLV-1 and HTLV-2 infection among different population in Central China. PLoS ONE 2013, 8, e66795. [CrossRef] [PubMed]

103. Ishak, R.; Cavalcante, F.; Vallinoto, A.C.; Azevedo, V.N.; Ishak, M.O. HTLV-I associated myelopathy in the northern region of Brazil (Belém-Pará): Serological and clinical features of three cases. Rev. Soc. Bras. Med. Trop. 2002, 35, 243-246. [CrossRef] [PubMed]

104. Vallinoto, A.C.; Santana, B.B.; dos Santos, E.L.; Santo, R.R.; Hermes, R.B.; Sousa, R.C.; Cayres-Vallinoto, I.; Machado, L.F.; Ishak, M.O.; Ishak, R. FAS-670A/G single nucleotide polymorphism may be associated with human T lymphotropic virus-1 infection and clinical evolution to TSP/HAM. Virus Res. 2012, 163, 178-182. [CrossRef]

105. Queiroz, M.A.F.; Amoras, E.D.S.G.; Moura, T.C.F.; da Costa, C.A.; de Sousa, M.S.; Lima, S.S.; Ishak, R.; Vallinoto, A.C.R. The SAMHD1rs6029941 (A/G) Polymorphism Seems to Influence the HTLV-1 Proviral Load and IFN-Alpha Levels. Front. Cell. Infect. Microbiol. 2020, 10, 246. [CrossRef]

106. da Costa, C.A.; Furtado, K.C.; Ferreira, L.D.S.C.; de Souza Almeida, D.; Linhares Ada, C.; Ishak, R.; Vallinoto, A.C.; de Lemos, J.A.; Martins, L.C.; Ishikawa, E.A.; et al. Familial transmission of human T-cell lymphotrophic virus: Silent dissemination of an emerging but neglected infection. PLoS Negl. Trop. Dis. 2013, 7, e2272. [CrossRef]

107. Vallinoto, A.C.R.; Santana, B.B.; Queiroz, M.A.F.; da Silva, A.N.M.R.; Cayres-Vallinoto, I.M.V.; da Costa, C.A.; de Sousa, M.S.; Ishak, R. Family Aggregation of HTLV-1 Infection Associated with FAS -670A/G Polymorphism: A Case Report. Front. Microbiol. 2018, 8, 2685. [CrossRef]

108. Santana, B.B.; Queiroz, M.A.F.; Cerveira, R.A.; Rodrigues, C.M.; da Silva Graça Amoras, E.; da Costa, C.A.; de Sousa, M.S.; Ishak, R.; Goulart, L.R.; Vallinoto, A.C.R. Low Annexin A1 level in HTLV-1 infected patients is a potential biomarker for the clinical progression and diagnosis of HAM/TSP. BMC Infect. Dis. 2021, 21, 219. [CrossRef] [PubMed]

109. Normando, V.M.F.; Dias, Á.R.N.; da Silva, A.L.S.E.; da Silva Pinto, D.; de Souza Santos, M.C.; Rodrigues, C.L.; de Oliveira, E.M.; de Souza Filho, L.E.C.; de Brito Vieira, W.; Andriolo, R.B.; et al. HTLV-I induces lesions in the pulmonary system: A systematic review. Life Sci. 2020, 256, 117979. [CrossRef] [PubMed]

110. World Health Organization. Human Papillomavirus (HPV) and Cervical Cancer. 2018. Available online: https://www.who.int/ en/news-room/fact-sheets/detail/human-papillomavirus-(hpv)-and-cervical-cancer (accessed on 21 February 2021).

111. International Human Papillomavirus Reference Center. Reference clones, Stockholm: Karolinska Institutet. Available online: https:/ / www.hpvcenter.se/human_reference_clones/ (accessed on 5 March 2021).

112. Schiffman, M.; Doorbar, J.; Wentzensen, N.; de Sanjosé, S.; Fakhry, C.; Monk, B.J.; Stanley, M.A.; Franceschi, S. Carcinogenic human papillomavirus infection. Nat. Rev. Dis. Prim. 2016, 2, 16086. [CrossRef] [PubMed]

113. Colpani, V.; Soares Falcetta, F.; Bacelo Bidinotto, A.; Kops, N.L.; Falavigna, M.; Serpa Hammes, L.; Schwartz Benzaken, A.; Kalume Maranhão, A.G.; Domingues, C.M.A.S. Prevalence of human papillomavirus (HPV) in Brazil: A systematic review and meta-analysis. PLoS ONE 2020, 15, e0229154. [CrossRef] [PubMed]

114. Brito, E.B.; Silva, I.D.; Stávale, J.N.; Taromaru, E.; Menezes, R.C.; Martins, S.J. Amerindian women of the Brazilian Amazon and STD. Eur. J. Gynaecol. Oncol. 2006, 27, 279-281.

115. Fonseca, A.J.; Taeko, D.; Chaves, T.A.; Amorim, L.D.; Murari, R.S.; Miranda, A.E.; Chen, Z.; Burk, R.D.; Ferreira, L.C. HPV Infection and cervical screening in socially isolated indigenous women inhabitants of the Amazonian Rainforest. PLoS ONE 2015, 10, e0133635. [CrossRef]

116. Noronha, V.; Mello, W.; Villa, L.; Brito, A.; Macêdo, R.; Bisi, F.; Mota, R.; Sassamoto, K.; Monteiro, T.; Linhares, A. Human papillomavirus associated with uterine cervix lesions. Rev. Soc. Bras. Med. Trop. 1999, 32, 235-240. [CrossRef]

117. Junes-Gill, K.; Sichero, L.; Maciag, P.C.; Mello, W.; Noronha, V.; Villa, L.L. Human papillomavirus type 16 variants in cervical cancer from an admixtured population in Brazil. J. Med. Virol. 2008, 80, 1639-1645. [CrossRef]

118. Duarte, D.V.; Vieira, R.C.; Brito, E.B.; Pinheiro, M.D.C.N.; Monteiro, J.D.S.V.; Valente, M.D.R.; Ishikawa, E.A.Y.; Fuzii, H.T.; Sousa, M.S. Prevalence of human papillomavirus infection and cervical cancer screening among riverside women of the Brazilian Amazon. Rev. Bras. Ginecol. Obstet. 2017, 39, 350-357. [CrossRef]

119. Moreira, D.P.; Gonzaga, G.J.R.; Lopes, T.A.M.; Galvão, R.S. Molecular detection of human papillomavirus in women sex workers in the center-south area of Manaus-AM. Braz. J. Hea. Rev. 2020, 3, 9454-9463.

120. de Aguiar, S.R.; Villanova, F.E.; Martins, L.C.; dos Santos, M.S.; de Maciel, J.P.; Falcão, L.F.; Fuzii, H.T.; Quaresma, J.A. Human papillomavirus: Prevalence and factors associated in women prisoners population from the Eastern Brazilian Amazon. J. Med. Virol. 2014, 86, 1528-1533. [CrossRef] [PubMed]

121. Conde, S.R.; de Móia, J.L.; Barbosa, M.S.; Miranda, E.C.; Brito, E.M.; de Araújo, M.T.; Demachki, S. Prevalence of hepatitis B virus genotypes and the occurrence of precore mutation A-1896 and to correlate them with the clinical presentation of chronic hepatitis.; in a population group of the Eastern Amazon region. Rev. Soc. Bras. Med. Trop. 2004, 37, 33-39. [CrossRef]

122. Fuzi, H.T.; Quaresma, J.A. Prevalence of genital HPV infection in urban and rural women in the Eastern Brazilian Amazon. Cad Saude Publ. 2011, 27, 769-778.

123. Torres, K.L.; Mariño, J.M.; Pires, R.D.A.; de Mello, M.B.; de Melo, F.H.H.; Reis, R.D.S.; Alves, V.D.C.R.; Gomes, E.; Martins, T.R.; Soares, A.C.; et al. Self-sampling coupled to the detection of HPV 16 and 18 E6 protein: A promising option for detection of cervical malignancies in remote areas. PLoS ONE 2018, 13, e0201262. [CrossRef] [PubMed] 
124. Vieira, R.C.; Monteiro, J.D.S.V.; Manso, E.P.; Dos Santos, M.R.; Tsutsumi, M.Y.; Ishikawa, E.A.; Ferrari, S.F.; Lima, K.V.; de Sousa, M.S. Prevalence of type-specific HPV among female university students from northern Brazil. Infect. Agent Cancer 2015, 10, 21. [CrossRef]

125. Amaral, J.L.; Araújo, M.V.; Dias, G.A.; Ledebur, E.I.; Quaresma, J.A.; Fuzi, H.T. Clinical and epidemiological study of human papillomavirus infection in women with systemic lupus erythematosus in eastern brazilian amazon. Acta Reumatol. Port. 2017, 42, 47-54. [PubMed]

126. Araújo, M.V.; Pinheiro, H.H.; de Pinheiro, J.J.; Quaresma, J.A.; Fuzi, H.T.; Medeiros, R.C. Prevalence of human papillomavirus (HPV) in Belem.; Para State.; Brazil.; in the oral cavity of individuals without clinically diagnosable injuries. Cad Saude Publ. 2014, 30, 1115-1119. [CrossRef]

127. Rodrigues, M.S.A.; Nascimento, R.S.; Fonseca, R.R.S.; Silva-Oliveira, G.C.; Machado, L.F.A.; Kupek, E.; Fischer, B.; Oliveira-Filho, A.B. Oral HPV among people who use crack-cocaine: Prevalence.; genotypes.; risk factors.; and key interventions in a remote Northern Brazilian region. Clin. Oral Investig. 2020, 25, 759-767. [CrossRef]

128. Lin, C.; Slama, J.; Gonzalez, P.; Goodman, M.T.; Xia, N.; Kreimer, A.R.; Hessol, N.A.; Shvetsov, Y.; Ortiz, A.P.; Grinsztejn, B.; et al. Cervical determinants of anal HPV infection and high-grade anal lesions in women: A collaborative pooled analysis. Lancet Infect. Dis. 2019, 19, 880-891. [CrossRef]

129. World Health Organization. Hepatitis B. 2020. Available online: https://www.who.int/news-room/fact-sheets/detail/hepatitisb (accessed on 13 February 2021).

130. Bensabath, G.; Soares, M.C. The evolution of knowledge about viral hepatitis in Amazon region: From epidemiology and etiology to the prophilaxy. Rev. Soc. Bras. Med. Trop. 2004, 37 (Suppl. 2), 14-26. [CrossRef]

131. Souto, F.J. Distribution of hepatitis B infection in Brazil: The epidemiological situation at the beginning of the 21st century. Rev. Soc. Bras. Med. Trop. 2016, 49, 11-23. [CrossRef] [PubMed]

132. Bensabath, G.; Boshell, J. Presence of Australian (Au) antigen in population groups of the interior of the State of Amazonas, Brazil. Rev. Inst. Med. Trop. Sao Paulo 1973, 15, 284-288. [PubMed]

133. Bensabath, G.; Hadler, S.C.; Soares, M.C.; Fields, H.; Dias, L.B.; Popper, H.; Maynard, J.E. Hepatitis delta virus infection and Labrea hepatitis. Prevalence and role in fulminant hepatitis in the Amazon Basin. JAMA 1987, 258, 479-483. [CrossRef] [PubMed]

134. Brasil. Boletim Epidemiológico Anual de Hepatites Virais. 2019. Available online: http://www.aids.gov.br/pt-br/pub/2020 /boletim-epidemiologico-hepatites-virais-2020 (accessed on 18 February 2021).

135. Gomes, C.; Wong, R.J.; Gish, R.G. Global Perspective on Hepatitis B virus infections in the era of effective vaccines. Clin. Liver Dis. 2019, 23, 383-399. [CrossRef] [PubMed]

136. MacLachlan, J.H.; Cowie, B.C. Hepatitis B virus epidemiology. Cold Spring Harb. Perspect. Med. 2015, 5, a021410. [CrossRef] [PubMed]

137. Fonseca, J.C.; Simonetti, S.R.; Schatzmayr, H.G.; Castejón, M.J.; Cesário, A.L.; Simonetti, J.P. Prevalence of infection with hepatitis delta virus (HDV) among carriers of hepatitis B surface antigen in Amazonas State.; Brazil. Trans. R. Soc. Trop. Med. Hyg. 1988, 82, 469-471. [CrossRef]

138. Rizzetto, M. Hepatitis D: Thirty years after. J. Hepatol. 2009, 50, 1043-1050. [CrossRef]

139. Santos, A.K.; Ishak, M.O.; Santos, S.E.; Guerreiro, J.F.; Ishak, R. A possible correlation between the host genetic background in the epidemiology of hepatitis B virus in the Amazon region of Brazil. Mem. Inst. Oswaldo Cruz. 1995, 90, 435-442. [CrossRef] [PubMed]

140. Vieira-Filho, J.B.; Cruz, C.F.N.; Kemp, L.; Santos, O.M.; Guimarães, R.X. Prevalência de marcadores sorológicos do HBV em indígenas do Sudeste do Pará. GED 1990, 9, 35-36.

141. Miranda, N.T.G.P.; de Souza, R.L.; Monteiro, J.C.; Costa, I.B.; Siravenha, L.Q.; da Luz, A.L.B.; de Almeida, N.C.C.; Oliveira-Filho, A.B.; Laurentino, R.V.; Machado, L.F.A. Seroprevalence of HBV and HCV in female sex workers from four cities in the state of Para, northern Brazil. J. Med. Virol. 2020, 93, 3730-3737. [CrossRef]

142. Frade, P.C.R.; Raiol, N.C.; da Costa, L.M.; Pinheiro, L.M.L.; Silva-Oliveira, G.C.; Pinho, J.R.R.; Lemos, J.A.R.; Martins, L.C.; Oliveira-Filho, A.B. Factors associated with exposure to hepatitis B virus in female sex workers from the Marajo Archipelago, northern Brazil. Int. J. STD AIDS 2019, 30, 1127-1128. [CrossRef]

143. Frade, P.C.; Raiol, N.C.; da Costa, L.M.; Pinheiro, L.M.; Silva-Oliveira, G.C.; Pinho, J.R.; Lemos, J.A.; Martins, L.C.; Oliveira-Filho, A.B. Prevalence and genotyping of hepatitis B virus: A cross-sectional study conducted with female sex workers in the Marajo Archipelago, Brazil. Int. J. STD AIDS 2019, 30, 902-910. [CrossRef] [PubMed]

144. Conde, S.R.; Feitosa, R.N.; Freitas, F.B.; Hermes, R.B.; Demachki, S.; Araújo, M.T.; Soares, M.C.; Ishak, R.; Vallinoto, A.C. Association of cytokine gene polymorphisms and serum concentrations with the outcome of chronic hepatitis B. Cytokine 2013, 61, 940-944. [CrossRef] [PubMed]

145. Conde, S.R.; Rocha, L.L.; Ferreira, V.M.; Monteiro, J.C.; Filgueiras, N.K.; Lins, P.A.; dos Santos, B.T.; Freitas, F.B.; Da Silva Graça, E.; Demachki, S.; et al. Absence of correlation between IL-28B gene polymorphisms and the clinical presentation of chronic hepatitis B in an Amazon Brazilian population. Dis. Mark. 2014, 2014, 534534.

146. Sá, K.S.; Pires-Neto, O.D.S.; Santana, B.B.; Gomes, S.T.; Amoras, E.D.S.G.; Conde, S.R.; Demachki, S.; Azevedo, V.N.; Machado, L.F.; Martins-Feitosa, R.N.; et al. Toll-like receptor 3 gene polymorphisms are not associated with the risk of hepatitis B and hepatitis C virus infection. Rev. Soc. Bras. Med. Trop. 2015, 48, 136-142. [CrossRef] 
147. Moura, T.C.; Amoras, E.D.; Araújo, M.S.; Freitas Queiroz, M.A.; Conde, S.R.; Demachki, S.; Martins-Feitosa, R.N.; Machado, L.F.; Cayres-Vallinoto, I.M.; Ishak, R.; et al. HBV viral load and liver enzyme levels may be associated with the wild MBL2 AA genotype. Mediat. Inflamm. 2017, 2017, 3718451. [CrossRef]

148. Pereira, L.M.S.; Amoras, E.D.S.G.; da Silva Conde, S.R.S.; Demachki, S.; Monteiro, J.C.; Martins-Feitosa, R.N.; da Silva, A.N.M.R.; Ishak, R.; Vallinoto, A.C.R. The -3279C >A and -924A>G polymorphisms in the FOXP3 Gene Are associated with viral load and liver enzyme levels in patients with chronic viral liver diseases. Front. Immunol. 2018, 9, 2014. [CrossRef]

149. da Amoras, S.E.; Gomes, S.T.; Freitas, F.B.; Santana, B.B.; Ishak, G.; de Araújo, M.T.; Demachki, S.; da Silva Conde, S.R.; de Oliveira Guimarães Ishak, M.; Ishak, R.; et al. NGF and P75NTR gene expression is associated with the hepatic fibrosis stage due to viral and non-viral causes. PLoS ONE 2015, 10, e0121754. [CrossRef] [PubMed]

150. Peeling, R.W.; Mabey, D.; Kamb, M.L.; Chen, X.S.; Radolf, J.D.; Benzaken, A.S. Syphilis. Nat. Rev. Dis. Prim. 2017, $12,17073$. [CrossRef]

151. Korenromp, E.L.; Rowley, J.; Alonso, M.; Mello, M.B.; Wijesooriya, N.S.; Mahiané, S.G.; Ishikawa, N.; Le, L.V.; Newman-Owiredu, M.; Nagelkerke, N.; et al. Global burden of maternal and congenital syphilis and associated adverse birth outcomes-Estimates for 2016 and progress since 2012. PLoS ONE 2019, 14, e0211720.

152. Brail. Boletim Epidemiológico Anual de Sífilis. 2020. Available online: http://www.aids.gov.br/pt-br/pub/2020/boletim-sifilis2020 (accessed on 1 February 2021).

153. Vallinoto, A.C.R.; Santos, D.A.; Rosal, E.C.; Pontes, G.S.; Rodrigues, A.M.V.; Machado, L.F.A. Avaliação sorológica e fatores de risco associados à sífilis. Rev. Para. Med. 2003, 17, 29-33.

154. Novak, R.M.; Ghanem, A.; Hart, R.; Ward, D.; Armon, C.; Buchacz, K. HIV Outpatient Study Investigators: Risk factors and incidence of syphilis in HIV-infected persons.; the HIV outpatient study, 1999-2015. Clin. Infect. Dis. 2018, 67, 1750-1759. [CrossRef]

155. Souza, R.L.; dos Santos Madeira, L.D.P.; Pereira, M.V.S.; da Silva, R.M.; de Luna Sales, J.B.; Azevedo, V.N.; Feitosa, R.N.M.; Monteiro, J.C.; de Oliveira Guimarães Ishak, M.; Ishak, R.; et al. Prevalence of syphilis in female sex workers in three countryside cities of the state of Pará, Brazilian Amazon. BMC Infect. Dis. 2020, 20, 129.

156. Coelho, E.C.; Souza, S.B.; Costa, C.C.S.; Costa, L.M.; Pinheiro, L.M.L.; Machado, L.F.A.; Silva-Oliveira, G.C.; Martins, L.C.; Frade, P.C.R.; Oliveira-Filho, A.B. Treponema pallidum in female sex workers from the Brazilian Marajo Archipelago: Prevalence.; risk factors.; drug-resistant mutations and coinfections. Trans. R. Soc. Trop. Med. Hyg. 2020, 18, raa127. [CrossRef]

157. Ferreira, G.R.O.N.; Freitas, F.B.; Queiroz, M.A.F.; Lima, S.S.; Vallinoto, A.C.R.; de O Guimarães Ishak, M.; Ishak, R. Epidemiology and risk factors for chlamydia trachomatis, treponema pallidum, Hepatitis B Virus and Hepatitis C Virus in the Marajó Archipelago, Brazilian Amazon. J. Community Med. Health Educ. 2019, 9, 643.

158. Schachter, J.; Caldwell, H.D. Chlamydiae. Ann. Rev. Microbiol. 1980, 34, 285-309. [CrossRef] [PubMed]

159. Oriel, J.D.; Ridgway, G.L. Epidemiology of chlamydial infection of the human genital tract: Evidence for the existence of latent infections. Eur. J. Clin. Microbiol. 1982, 1, 69-75. [CrossRef]

160. Wilfert, C.M.; Gutman, L.T. Chlamydia trachomatis infections of infants and children. Adv. Pediatr. 1986, 33, 49-75.

161. Morré, S.A.; Meijer, C.J.; Munk, C.; Krüger-Kjaer, S.; Winther, J.F.; Jørgensens, H.O.; van Den Brule, A.J. Pooling of urine specimens for detection of asymptomatic Chlamydia trachomatis infections by PCR in a low-prevalence population: Cost-saving strategy for epidemiological studies and screening programs. J. Clin. Microbiol. 2000, 38, 1679-1680. [CrossRef]

162. Friberg, J.; Gleicher, N.; Suarez, M.; Confino, E. Chlamydia attached to spermatozoa. J. Infect. Dis. 1985, 152, 854. [CrossRef]

163. Washington, A.E.; Johnson, R.E.; Sanders, L.L., Jr. Chlamydia trachomatis infections in the United States. What are they costing us? JAMA 1987, 17, 2070-2072. [CrossRef]

164. Akande, V.A.; Hunt, L.P.; Cahill, D.J.; Caul, E.O.; Ford, W.C.; Jenkins, J.M. Tubal damage in infertile women: Prediction using chlamydia serology. Hum. Reprod. 2003, 18, 1841-1847. [CrossRef]

165. Peeling, R.W.; Brunham, R.C. Chlamydiae as pathogens: New species and new issues. Emerg. Infect. Dis. 1996, 2, 307-319. [CrossRef] [PubMed]

166. Pathela, P.; Blank, S.; Schillinger, J.A. Lymphogranuloma venereum: Old pathogen, new story. Curr. Infect. Dis. Rep. 2007, 9, 143-150. [CrossRef] [PubMed]

167. de O Ishak, M.; Mumtaz, G.; Ishak, R.; Ridgway, G. Prevalence of antibodies to Chlamydia trachomatis in population groups of Brazil; England and Portugal. Rev. Inst. Med. Trop. Sao Paulo 1988, 30, 40-44.

168. Magalhaes, M.; Andrade, M.; Veras, A. Uretrites não gonocócicas masculinas associdas a Chlamydia.; Ureaplasma e Trichomonas. Rev. Microbiol. 1982, 13, 156160.

169. Peeters, M.; Chaix, M.L.; Delaporte, E. Genetic diversity and phylogeographic distribution of SIV: How to understand the origin of HIV. Med. Sci. 2008, 24, 621-628.

170. Wolfe, N.D.; Heneine, W.; Carr, J.K.; Garcia, A.D.; Shanmugam, V.; Tamoufe, U.; Torimiro, J.N.; Prosser, A.T.; Lebreton, M.; Mpoudi-Ngole, E.; et al. Emergence of unique primate T-lymphotropic viruses among central African bushmeat hunters. Proc. Natl. Acad. Sci. USA 2005, 102, 7994-7999. [CrossRef]

171. Andersen, K.G.; Rambaut, A.; Lipkin, W.I.; Holmes, E.C.; Garry, R.F. The proximal origin of SARS-CoV-2. Nat. Med. 2020, 26, 450-452. [CrossRef]

172. Black, F.L.; Hierholzer, W.J.; Pinheiro, F.; Evans, A.S.; Woodall, J.P.; Opton, E.M.; Emmons, J.E.; West, B.S.; Edsall, G.; Downs, W.G.; et al. Evidence for persistence of infectious agents in isolated human populations. Am. J. Epidemiol. 1974, 100, 230-250. [CrossRef] 
173. Lee, R.V.; Black, F.L.; Hierholzer, W.J., Jr.; West, B.L. A novel pattern of treponemal antibody distribution in isolated South American Indian populations. Am. J. Epidemiol. 1978, 107, 46-53. [CrossRef] [PubMed]

174. Vidhani, S.; Mehta, S.; Bhalla, P.; Bhalla, R.; Sharma, V.K.; Batra, S. Seroprevalence of Chalmydia trachomatis infection amongst patients with pelvic inflammatory diseases and infertility. J. Commun. Dis. 2005, 37, 233-238. [PubMed]

175. Panchaud, C.; Singh, S.; Feivelson, D.; Darroch, J.E. Sexually transmitted diseases among adolescents in developed countries Fam. Plann. Perspect. 2000, 32, 24-32. [CrossRef] [PubMed]

176. Signorini, D.J.; Monteiro, M.C.; de Sá, C.A.; Sion, F.S.; Leitão Neto, H.G.; Lima, D.P.; Machado, J.D. Prevalence of HIV-syphilis coinfection in a university hospital in the city of Rio de Janeiro in 2005. Rev. Soc. Bras. Med. Trop. 2007, 40, 282-285. [CrossRef] [PubMed]

177. Chen, M.Y.; Fairley, C.K.; De Guingand, D.; Hocking, J.; Tabrizi, S.; Wallace, E.M.; Grover, S.; Gurrin, L.; Carter, R.; Pirotta, M.; et al. Screening pregnant women for chlamydia: What are the predictors of infection? Sex Transm. Infect. 2009, 85, 31-35. [CrossRef] [PubMed]

178. Evans, C.; Das, C.; Kinghorn, G. A retrospective study of recurrent chlamydia infection in men and women: Is there a role for targeted screening for those at risk? Int. J. STD AIDS 2009, 20, 188-192. [CrossRef]

179. de O Ishak, M.; Costa, M.M.; Almeida, N.C.; Santiago, A.M.; Brito, W.B.; Vallinoto, A.C.; Azevedo, V.N.; Ishak, R. Chlamydia trachomatis serotype A infections in the Amazon region of Brazil: Prevalence.; entry and dissemination. Rev. Soc. Bras. Med. Trop. 2015, 48, 170-174.

180. Santos, M.A.S.; Santana, A.C.; Rebello, F.K. Rural Credit Policy in the Marajó Archipelago.; State of Pará: An Analysis of the Period 2000-2010. Society and Rural Development online. 2013. Available online: https://www.climatepolicyinitiative.org/ publication/rural-credit-policy-in-brazil-agriculture-environmental-protection-and-economic-development/ (accessed on 22 February 2021).

181. Miranda Costa, E. Degree in Field Education: Intentionalities in the formation of educators of the field in the Marajó. Educación 2017, 26, 88-103. [CrossRef]

182. World Health Organization. Trachoma. Fact Sheet, Update in April 2017. Available online: http://www.who.int/mediacentre/ factsheets/fs382/en/ (accessed on 2 March 2021).

183. Freitas, C.A. Prevalência do tracoma no Brasil. Rev. Bras. Malariol. Doencas. Trop. 1976, 28, 227-233.

184. Ishak, R.; Machado, L.F.A.; Cayres-Vallinoto, I.; Guimarães Ishak, M.O.; Vallinoto, A.C.R. Infectious agents as markers of human migration toward the Amazon Region of Brazil. Front. Microbiol. 2017, 8, 1663. [CrossRef]

185. Yamazaki, T.; Matsumoto, M.; Matsuo, J.; Abe, K.; Minami, K.; Yamaguchi, H. Frequency of Chlamydia trachomatis in Ureaplasmapositive healthy women attending their first prenatal visit in a community hospital in Sapporo, Japan. BMC Infect. Dis. 2012, 12, 82. [CrossRef]

186. Reilly, L.A.; Favacho, J.; Garcez, L.M.; Courtenay, O. Preliminary evidence that synanthropic flies contribute to the transmission of trachoma-causing Chlamydia trachomatis in Latin America. Cad Saude Publ. 2007, 23, 1682-1688. [CrossRef] [PubMed]

187. Favacho, J.; Alves da Cunha, A.J.L.; Gomes, S.T.M.; Freitas, F.B.; Queiroz, M.A.F. Prevalence of trachoma in school children in the Marajó Archipelago, Brazilian Amazon, and the impact of the introduction of educational and preventive measures on the disease over eight years. PLoS Negl. Trop. Dis. 2018, 12, e0006282. [CrossRef] [PubMed]

188. Atlas do Desenvolvimento Humano no Brasil. IDHM 2013. Available online: http://www.atlasbrasil.org.br/2013/pt/consulta/ (accessed on 28 February 2021).

189. Pinar, A.; Oç, M.; Akyön, Y.; Farsak, B.; Koçyildirim, E.; Us, D.; Zorlutuna, Y.; Tokgözoğlu, L.; Böke, E. The presence of Chlamydophila pneumoniae.; Helicobacter pylori and cytomegalovirus in human atherosclerosis detected by molecular and serological methods. Mikrobiyol. Bull. 2004, 38, 213-222.

190. Nazmi, A.; Diez-Roux, A.V.; Jenny, N.S.; Tsai, M.Y.; Szklo, M.; Aiello, A.E. The influence of persistent pathogens on circulating levels of inflammatory markers: A cross-sectional analysis from the MultiEthnic Study of Atherosclerosis. BMC Public Health 2010, 10, 706. [CrossRef] [PubMed]

191. Bayram, A.; Erdogan, M.B.; Eksi, F.; Yamak, B. Demonstration of Chlamydophila pneumoniae, Mycoplasma pneumoniae, Cytomegalovirus, and Epstein-Barr virus in atherosclerotic coronary arteries, nonrheumatic calcific aortic and rheumatic stenotic mitral valves by polymerase chain reaction. Anadolu Kardiyol. Derg. 2011, 11, 237-243. [CrossRef]

192. Queiroz, M.A.; Gomes, S.T.; Almeida, N.C.; Souza, M.I.; Costa, S.R.; Hermes, R.B.; Lima, S.S.; Zaninotto, M.M.; Fossa, M.A.; Maneschy, M.A.; et al. Mannose-binding lectin 2 (Mbl2) gene polymorphisms are related to protein plasma levels.; but not to heart disease and infection by Chlamydia. Braz. J. Med. Biol. Res. 2016, 49, e5519. [CrossRef] 